\title{
Study of pallial neurogenesis in shark embryos and the evolutionary origin of the subventricular zone
}

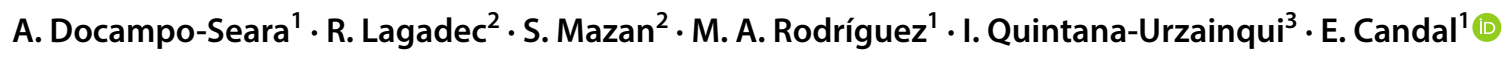

Received: 9 January 2018 / Accepted: 19 June 2018 / Published online: 6 July 2018

(c) The Author(s) 2018

\begin{abstract}
The dorsal part of the developing telencephalon is one of the brain areas that has suffered most drastic changes throughout vertebrate evolution. Its evolutionary increase in complexity was thought to be partly achieved by the appearance of a new neurogenic niche in the embryonic subventricular zone (SVZ). Here, a new kind of amplifying progenitors (basal progenitors) expressing Tbr2, undergo a second round of divisions, which is believed to have contributed to the expansion of the neocortex. Accordingly, the existence of a pallial SVZ has been classically considered exclusive of mammals. However, the lack of studies in ancient vertebrates precludes any clear conclusion about the evolutionary origin of the SVZ and the neurogenic mechanisms that rule pallial development. In this work, we explore pallial neurogenesis in a basal vertebrate, the shark Scyliorhinus canicula, through the study of the expression patterns of several neurogenic markers. We found that apical progenitors and radial migration are present in sharks, and therefore, their presence must be highly conserved throughout evolution. Surprisingly, we detected a subventricular band of ScTbr2-expressing cells, some of which also expressed mitotic markers, indicating that the existence of basal progenitors should be considered an ancestral condition rather than a novelty of mammals or amniotes. Finally, we report that the transcriptional program for the specification of glutamatergic pallial cells (Pax6, Tbr2, NeuroD, Tbr1) is also present in sharks. However, the segregation of these markers into different cell types is not clear yet, which may be linked to the lack of layering in anamniotes.
\end{abstract}

Keywords Pallium $\cdot$ Apical progenitors $\cdot$ Radial migration $\cdot \mathrm{SVZ} \cdot \mathrm{Tbr} 2 \cdot \mathrm{Tbr} 1$

I. Quintana-Urzainqui and E. Candal1 contributed equally to this work.

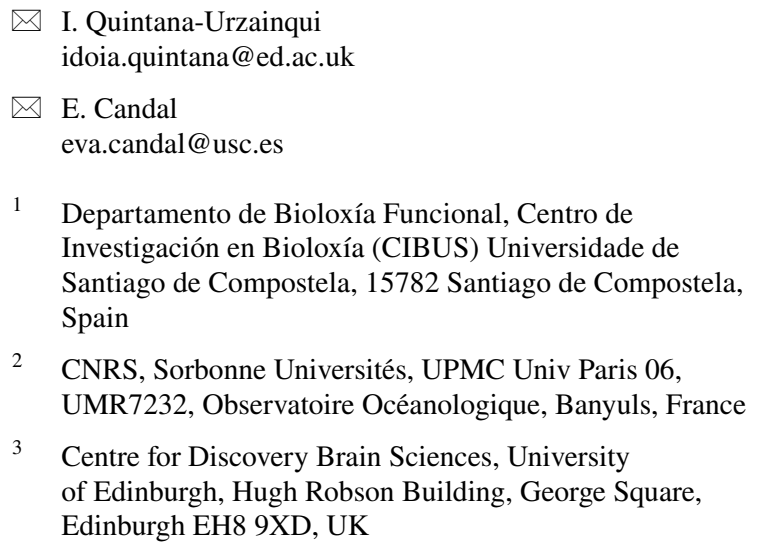

1 Departamento de Bioloxía Funcional, Centro de Investigación en Bioloxía (CIBUS) Universidade de Santiago de Compostela, 15782 Santiago de Compostela, Spain

2 CNRS, Sorbonne Universités, UPMC Univ Paris 06, UMR7232, Observatoire Océanologique, Banyuls, France

3 Centre for Discovery Brain Sciences, University of Edinburgh, Hugh Robson Building, George Square, Edinburgh EH8 9XD, UK$$
\text { Edinburgh EH8 9XD, UK }
$$

\section{Introduction}

The telencephalon, as one of the most complex structures in the brain, has roles in decision making, memory, learning or higher cognitive behavior, and thus, has been a major subject of interest for many researchers. One of its subdivisions is the mammalian cerebral cortex which is more generally called the vertebrate dorsal pallium. An important difference in the dorsal pallium/cortex among vertebrates is the absence of layers in amphibians and fishes in contrast to the three-layered structure observed in reptiles or the six-layered cortices present in mammals (Abdel-Mannan et al. 2008). Surprisingly, the neurogenic and migratory pattern operating during the development of this pallial subdivision seems to show more similarities across vertebrates than expected (Medina and Abellán 2009; Wullimann 2009; Montiel et al. 2015; Quintana-Urzainqui et al. 2015).

Neurogenesis is the process by which new neurons are formed from stem cells through orderly sequenced events occurring both during development and in the adult life 
(Götz and Huttner 2005; Espósito et al. 2005; Hevner et al. 2006). Neurogenesis involves a natural transition from a proliferating undifferentiated progenitor to a postmitotic and terminally differentiated neuron, which is usually accompanied by the migration and displacement of cells to their final position (Noctor et al. 2004; Hevner et al. 2006). During the course of pallial development, neuroepithelial cells, the primary neural stem/progenitor cells, undergo both symmetric and asymmetric types of cell division to maintain the progenitor pool. Neuroepithelial cells generate, by asymmetric division, secondary neural stem cells termed radial glial progenitors (apical progenitors) [for review see Götz and Huttner (2005) and; Farkas and Huttner (2008)]. Radial glial progenitors express the proliferating cell nuclear antigen (PCNA) and transcription factors such as Sox 2 and Pax6, as well as the glial fibrillary acid protein (GFAP) (Heins et al. 2002; Ferri et al. 2004; Englund et al. 2005; Favaro et al. 2009; Anthony and Heintz 2008; Götz et al. 2015; Martynoga et al. 2015). Radial glial progenitors either divide to generate immature neurons directly (direct pathway) or to generate intermediate (basal) progenitor cells (IPC) (indirect pathway) (Haubensak et al. 2004; Miyata et al. 2004; Noctor et al. 2004; Götz and Huttner 2005; Martínez-Cerdeño et al. 2006; Cheung et al. 2007; Marín and Müller 2014; Martynoga et al. 2015). IPCs migrate out of the ventricular zone establishing what is called a subventricular zone (SVZ). These cells are morphologically different to radial glial cells, they express different molecular factors and will divide to generate two new neuroblasts (Haubensak et al. 2004; Miyata et al. 2004; Noctor et al. 2004; Englund et al. 2005; Götz and Huttner 2005). This indirect pathway might have served as an amplification mechanism of neurogenesis since it allows to generate increased numbers of neurons from a single division of a radial glial cell than the direct pathway (Smart et al. 2002). The transition of radial glia stem cells to IPCs and the beginning of the migratory process is characterized by Pax 6 and Sox 2 downregulation. In turn, the downregulation of Pax6 and Sox 2 leads to the upregulation of different migratory factors in the IPCs. One of these factors is the stabilizing microtubule protein doublecortin (DCX), which acts regulating the organization and stability of microtubules in the IPCs and migrating neurons (Gleeson et al. 1998, 1999). T-box gene Tbr2 and the bHLH gene NeuroD are also expressed by IPCs (Hevner et al. 2006). The expression of Tbr2 is strongly associated with the IPC state and the beginning of the migratory process. Other than being expressed by basal progenitor cells (see above), Tbr2 expression is also considered to serve as marker for the glutamatergic lineage in the cortex (Englund et al. 2005; Hevner et al. 2006). The expression of NeuroD is associated not only with the migratory process but also with the start of neuronal differentiation and glutamatergic phenotype in the cortex (Guillemot et al. 2006). As differentiation proceeds, Tbr2 is downregulated and another T box gene, $T b r l$, is upregulated. Tbr 1 is expressed in postmitotic neurons in many areas of the brain, and its expression is also related to the glutamatergic neuronal linage (Hevner et al. 2003, 2006). Therefore, in mammals, the glutamatergic lineage transcriptional program has been characterized by the sequential expression of those transcription factors: Pax6-Tbr2-NeuroD-Tbr1. Glutamatergic cells of brain areas like the cortex, hippocampus, olfactory bulb or the cerebellum mainly follow this program of development (Englund et al. 2005; Hevner et al. 2006; Brill et al. 2009; Roybon et al. 2009; Hodge et al. 2012; Imamura and Greer 2013).

Analyzing data under an evolutionary point of view shows that radial glial cells acting as progenitor cells in the developing pallium are not exclusive of mammals. Studies in other vertebrates such as reptiles (Clinton et al. 2014; Martínez-Cerdeño et al. 2016), amphibians (Moreno and González 2017) or teleosts (Dong et al. 2012) have also identified proliferating radial glial cells during pallial development. In the same way, comparative studies about the existence of IPCs and the SVZ have been performed in different species of vertebrates. It is thought that the pallial SVZ appeared in evolution during the transition from reptiles to mammals (Cheung et al. 2007; Martínez-Cerdeño et al. 2016), though some elements of a mammalian SVZ are present in the reptilian cortices (reviewed in Montiel et al. 2015). Therefore, many authors have linked the evolutionary emergence of the pallial SVZ with the increased complexity, gyrification and the expansion of the mammalian cortex (Zecevic et al. 2005; Kriegstein et al. 2006; MartínezCerdeño et al. 2006; Cheung et al. 2007, 2010; Rakic 2009; Reillo et al. 2011; Rash et al. 2013). Despite a defined SVZ or IPCs have been found in the dorsal pallium of birds and reptiles, recent studies suggest the existence of IPC-like cells in amphibians, opening the question about the evolutionary origin of IPCs and the SVZ (Moreno and González 2017). Regarding the transcription program for the specification of glutamatergic cells, studies in zebrafish also suggested a rather conserved transcriptional program in the pallium (Mione et al. 2001; Wullimann and Rink 2001, 2002; Mueller and Wullimann 2003; Mueller et al. 2008; Wullimann 2009; Mueller and Wulliman 2016). Whether this program of development is conserved in other species is not known. Extending these comparative studies to basal vertebrates will be key to understand the evolution of the pallial structures.

In this study, we have chosen the lesser spotted dogfish Scyliorhinus canicula, a basal vertebrate that belongs to the group of Chondrichthyans or cartilaginous fishes. They represent an ancient radiation of gnathostome (jawed) vertebrates and are currently considered the sister group of gnathostomes with a bony skeleton that gave rise to land vertebrates. This out-group position makes chondrichthyans essential in assessing the ancestral organization of the 
brain of jawed vertebrates (Rodríguez-Moldes et al. 2017 and references therein). In contrast to bony fishes, the chondrichthyan telencephalon develops, as in tetrapods, by evagination. In addition, the telencephalon of this species is especially large compared to the rest of the brain; in fact, it represents the $50 \%$ of the cerebral mass of these species (Yopak et al. 2015). This fact, added to its slow development and high neurogenic capacity (Quintana-Urzainqui et al. 2015) makes the telencephalon of $S$. canicula a valid model for studying neurogenesis and development.

The main purpose of this work is to gain knowledge about the evolutionary mechanisms of pallial neurogenesis by studying this process in cartilaginous fishes, an out-group of other jawed vertebrates. In particular, we aimed at exploring the existence of potential basal progenitors (IPCs) and a SVZ and at investigating the presence of a glutamatergic lineage transcriptional program in the pallium. For this, we have performed a spatiotemporal analysis of the expression pattern of several markers such as ScSox2 (pluripotent cells), GFAP (marker of radial glia), PCNA (proliferating cells), PH3 (mitotic cells), BrdU (S-phase cells after BrdU incorporation into the newly synthesized DNA), Pax6 (pallial marker and neurogenic regulator), ScTbr2 (IPC and glutamatergic fate marker), DCX (migratory cells), ScNeuroD (postmitotic and migratory cells) and Tbr1 (immature cells and glutamatergic fate transcription factor), during key stages of pallial neurogenesis in S. canicula.

\section{Materials and methods}

\section{Experimental animals}

We have analysed 22 embryos of $S$. canicula from stages 29 (S29) to 32 (S32). Embryos were provided by the Marine Biological Model Supply Service of the CNRS UPMC Roscoff Biological Station (France). Embryos were also kindly provided by the aquarium of O Grove (Galicia, Spain). Embryos were staged by their external features according to Ballard et al. (1993). Eggs were raised in seawater tanks under standard conditions of temperature $\left(15-16{ }^{\circ} \mathrm{C}\right), \mathrm{pH}(7.5-8.5)$ and salinity $(35 \mathrm{~g} / \mathrm{L})$ and suitable measures were taken to minimize animal pain and discomfort. All procedures conformed to the guidelines established by the European Communities Council Directive of 22 September 2010 (2010/63/UE) and by Spanish Royal Decree $53 / 2013$ for animal experimentation and were approved by the Ethics Committee of the University of Santiago de Compostela.

\section{Tissue processing}

Embryos were deeply anesthetized with $0.5 \%$ tricaine methane sulfonate (MS- 222; Sigma, St. Louis, MO) in seawater and separated from the yolk before fixation in $4 \%$ paraformaldehyde (PFA) in elasmobranch's phosphate buffer [EPB: $0.1 \mathrm{M}$ phosphate buffer $(\mathrm{PB})$ containing $1.75 \%$ of urea, $\mathrm{pH}$ 7.4] for 48-72 $\mathrm{h}$ depending on the stage of development. Sharks at S32 were deeply anesthetized with MS-222 and then perfused intracardially with elasmobranch Ringer's solution (see Ferreiro-Galve et al. 2012a) followed by $4 \%$ PFA in EPB. Brains of S32 embryos were removed and postfixed in the same fixative for $24-48 \mathrm{~h}$ at $4{ }^{\circ} \mathrm{C}$. Subsequently, they were rinsed in PB saline (PBS), cryoprotected with $30 \%$ sucrose in PB, embedded in OCT compound (Tissue Tek, Torrance, CA, USA), and frozen with liquid nitrogen-cooled isopentane. Parallel series of sections (16 $\mu \mathrm{m}$ thick) were obtained in transverse or sagittal planes on a cryostat and mounted on Superfrost Plus slides (Menzel-Glasser, Madison, WI, USA).

\section{Immunohistochemistry}

Sections were pre-treated with $0.01 \mathrm{M}$ citrate buffer $\mathrm{pH}$ 6.0 for $30 \mathrm{~min}$ at $90{ }^{\circ} \mathrm{C}$ for heat-induced epitope retrieval and allowed to cool for $20 \mathrm{~min}$ at room temperature (RT). Sections were rinsed in $0.05 \mathrm{M}$ TBS pH 7.4 for $5 \mathrm{~min}$ and treated with $10 \% \mathrm{H}_{2} \mathrm{O}_{2}$ in TBS for 30 min at RT to block endogenous peroxidase activity. Sections were rinsed in $0.05 \mathrm{M}$ Tris-buffered saline (TBS; $\mathrm{pH}$ 7.4) for $5 \mathrm{~min}$ and incubated for $15 \mathrm{~h}$ at RT with primary antibodies (see Table 1). Sections were rinsed three times in 0.05 M TBS pH 7.4 for 10 min each, and incubated in the appropriate horseradish peroxidase coupled secondary antibody (see Table 1) for $1 \mathrm{~h}$ at RT. All dilutions were made with TBS containing 15\% normal goat serum (Millipore, Billerica, MA) $0.2 \%$ Triton X-100 (Sigma) and 2\% bovine serum albumin (BSA, Sigma). All incubations were carried out in a humid chamber. Then, sections were rinsed three times in $0.05 \mathrm{M}$ TBS $\mathrm{pH} 7.4$ for $10 \mathrm{~min}$ each. The immunoreaction was developed with $0.25 \mathrm{mg} / \mathrm{ml}$ diaminobenzidine (DAB) tetrahydrochloride (Sigma) in TBS pH 7.4 and $0.00075 \%$ $\mathrm{H}_{2} \mathrm{O}_{2}$, or with SIGMAFAST TM 3.3-DAB tablets as indicated by the manufacturers. In some procedures, $2.5 \mathrm{mg} / \mathrm{ml}$ nickel ammonium sulphate was added. Finally, the sections were dehydrated and coverslipped.

\section{Immunofluorescence}

For heat-induced epitope retrieval, sections were pre-treated with $0.01 \mathrm{M}$ citrate buffer (pH 6.0) for $30 \mathrm{~min}$ at $90{ }^{\circ} \mathrm{C}$ and allowed to cool for $20 \mathrm{~min}$ at RT. Sections were rinsed in $0.05 \mathrm{M}$ TBS pH 7.4 for $5 \mathrm{~min}$ and incubated approximately 
Table 1 Primary and secondary antibodies used

\begin{tabular}{|c|c|c|c|c|c|}
\hline Primary antibody & Source & Working dilution & Secondary antibody & Source & Working dilution \\
\hline GFAP & $\begin{array}{l}\text { Polyclonal rabbit anti- } \\
\text { GFAP } \\
\text { Dako (Cat. no Z0334) }\end{array}$ & $1: 500$ & $\begin{array}{l}\text { Goat anti-rabbit HRP } \\
\text { coupled }\end{array}$ & Dako, Glostrup, Denmark & $1: 200$ \\
\hline PCNA & $\begin{array}{l}\text { Monoclonal mouse anti- } \\
\text { PCNA Sigma (Cat. no } \\
\text { P8825) }\end{array}$ & $1: 500$ & $\begin{array}{l}\text { Goat anti-mouse } \\
\text { HRP coupled }\end{array}$ & Dako, Glostrup, Denmark & $1: 200$ \\
\hline Pax6 & $\begin{array}{l}\text { Polyclonal rabbit anti-Pax6 } \\
\text { Covance (Cat no PRB- } \\
\text { 278P) }\end{array}$ & $1: 300$ & $\begin{array}{l}\text { 488-conjugated donkey } \\
\text { anti-rabbit }\end{array}$ & $\begin{array}{l}\text { Alexa Fluor } \\
\text { Molecular Probes, Eugene, } \\
\text { OR }\end{array}$ & $1: 200$ \\
\hline DCX & $\begin{array}{l}\text { Polyclonal rabbit anti-DCX } \\
\text { Cell Signalling (Cat. no } \\
\text { 4604) }\end{array}$ & $1: 300$ & $\begin{array}{l}\text { 488-conjugated donkey } \\
\text { anti-mouse }\end{array}$ & $\begin{array}{l}\text { Alexa Fluor } \\
\text { Molecular Probes, Eugene, } \\
\text { OR }\end{array}$ & $1: 200$ \\
\hline PH3 & $\begin{array}{l}\text { Polyclonal rabbit anti-PH3 } \\
\text { Bio Technology (Cat. no } \\
\text { 06-570) }\end{array}$ & $1: 400$ & $\begin{array}{l}\text { 546-conjugated donkey } \\
\text { anti-rabbit }\end{array}$ & $\begin{array}{l}\text { Alexa Fluor } \\
\text { Molecular Probes, Eugene, } \\
\text { OR }\end{array}$ & $1: 200$ \\
\hline Tbr1 & $\begin{array}{l}\text { Polyclonal rabbit anti-Tbr1 } \\
\text { Chemicon (Cat. no } \\
\text { AB9616) } \\
\text { Millipore (Cat. no } \\
\text { AB10554) }\end{array}$ & $1: 200$ & $\begin{array}{l}\text { 546-conjugated donkey } \\
\text { anti-mouse }\end{array}$ & $\begin{array}{l}\text { Alexa Fluor } \\
\text { Molecular Probes, Eugene, } \\
\text { OR }\end{array}$ & $1: 200$ \\
\hline BrdU & $\begin{array}{l}\text { Monoclonal mouse anti- } \\
\text { BrdU } \\
\text { Millipore (Cat. no } \\
\text { MAB4072) }\end{array}$ & $1: 200$ & $\begin{array}{l}\text { 488-conjugated donkey } \\
\text { anti-mouse }\end{array}$ & $\begin{array}{l}\text { Alexa fluor } \\
\text { Molecular probes, eugene, } \\
\text { OR }\end{array}$ & $1: 200$ \\
\hline
\end{tabular}

for $15 \mathrm{~h}$ at RT with primary antibodies (see Table 1). Sections were rinsed three times in $0.05 \mathrm{M}$ TBS pH 7.4 for $10 \mathrm{~min}$ each, and incubated in the appropriate fluorescent dye-labeled secondary antibodies (see Table 1) for $1 \mathrm{~h}$ at RT. All dilutions were made with TBS containing 15\% normal donkey serum (Millipore, Billerica, MA) 0.2\% Triton X-100 (Sigma) and 2\% BSA (Sigma). All incubations were carried out in a humid chamber. Sections were rinsed three times in $0.05 \mathrm{M}$ TBS pH 7.4 for 10 min each and in distilled water for $30 \mathrm{~min}$. Sections were then allowed to dry for $30 \mathrm{~min}$ at $37{ }^{\circ} \mathrm{C}$, and mounted in MOWIOL 4-88 Reagent (Calbiochem, MerkKGaA, Darmstadt, Germany). Information about the primary and secondary antibodies is included in Table 1.

\section{BrdU labelling}

BrdU (5-bromo-2'-deoxyuridine, a synthetic nucleoside analog of thymidine; Sigma B5002) was administrated to embryos at S30 of development by immersion for $2.5 \mathrm{~h}$ in $10 \mathrm{mg} / \mathrm{ml}$ BrdU in oxygenated artificial sea water after opening the egg shell. Embryos were sacrificed at $24 \mathrm{~h}$ (S30) and 10 days (S31) after BrdU incorporation. For detection of BrdU, sections were incubated in $2 \mathrm{~N} \mathrm{HCl}$ for $30 \mathrm{~min}$ at $50{ }^{\circ} \mathrm{C}$ to denature DNA strands. $\mathrm{HCl}$ reaction was stopped by addition of $0.1 \mathrm{M}$ sodium tetraborate and sections were then rinsed in TBS for $10 \mathrm{~min}$ before antibody incubation. Sections were incubated with the monoclonal mouse anti-BrdU antibody (Millipore, Billerica, MA, USA; 1:200) at RT overnight and processed for immunofluorescence as described above.

\section{In situ hybridization}

We applied in situ hybridization (ISH) for S. canicula Sox2, Tbr2/Eomes and NeuroD1 (ScSox2, ScTbr2, and ScNeuroD1) genes. These probes were selected from a collection of $S$. canicula embryonic cDNA library (mixed stages S9-22) and submitted to high throughput EST sequencing (coordinated by Dr. Sylvie Mazan). Sense and antisense digoxigenin-UTP-labeled ScSox2, ScTbr2 and ScNeuroD1 were synthesized directly by transcription in vitro. ISH was performed on cryostat sections of S29-S31 embryos following standard protocols (Coolen et al. 2009). Briefly, sections were permeabilized with proteinase $\mathrm{K}$, hybridized with sense or antisense probes overnight at $65^{\circ} \mathrm{C}$ and incubated with the alkaline phosphatase-coupled anti-digoxigenin antibody (1:2000, Roche Applied Science, Manheim, Germany) overnight at $4{ }^{\circ} \mathrm{C}$. The colour reaction was performed in the presence of BM-Purple (Roche). Finally, sections were dehydrated and coverslipped. Control sense probes did not produce any detectable signal. For combined ISH-immunohistochemistry, after colorimetric detection of probes, sections were rinsed three times in $1 \mathrm{M}$ PBS for 10 min each and immunohistochemistry was performed as described above. 


\section{Control and specificity of antibodies}

The polyclonal antibody against GFAP has been widely used as a marker of glial cells in the brain, retina and olfactory system of S. canicula (Wasowicz 1999; Quintana-Urzainqui et al. 2014, 2015; Sánchez-Farías and Candal 2016). The PCNA antibody has been previously used to label progenitor cells in the brain, retina and olfactory system of the lesser spotted dogfish (Ferreiro-Galve et al. 2010; QuintanaUrzainqui et al. 2014, 2015; Sánchez-Farías and Candal 2015, among others). The PCNA is present in proliferating cells along the entire cell cycle, though its expression is stronger during the $\mathrm{S}$ phase of the cell cycle (Zerjatke et al. 2017). The specificity of the antibody against Pax6 has been tested by preabsorption test (Ferreiro-Galve et al. 2012b) and the specificity of the DCX has also been tested by western blot (Pose-Méndez et al. 2014). The anti-PH3 antibody has been used previously as a marker of mitotic cells in the brain and retina of S. canicula (Ferreiro-Galve et al. 2010; Quintana-Urzainqui et al. 2015). Tbr1 has been widely used as a marker of pallial/cortical neurons in the developing cortex of mammals and birds (Ceci et al. 2012; Pedraza and DeCarlos 2012; Ballout et al. 2016). The two polyclonal anti-Tbr 1 antibodies used in this study revealed a similar pattern of distribution of immunoreactive (-ir) cells and, therefore, descriptions of Tbr1-immunoreactivity in next section apply to both.

\section{Imaging}

Fluorescent sections were photographed with the Leica TCS-SP2 scanning microscope with a combination of blue and green excitation lasers. Confocal images were acquired separately for each laser channel with steps of $2 \mu \mathrm{m}$ along the $z$-axis, and collapsed images were obtained with the LITE software (Leica). Also some sections were photographed with an Olympus AX70 epifluorescence photomicroscope fitted with an Olympus DP70 colour digital camera. Light field images were obtained with an Olympus BX51 microscope equipped with an Olympus DP71 colour digital camera. Both fluorescent and light field photographs were adjusted for contrast, brightness and intensity using Corel Draw X3.

\section{Results}

During the development of the telencephalon in S. canic$u l a$, a neurogenic period has been established by QuintanaUrzainqui et al. (2015) from stage S28 to S31 of development. This period of development is roughly comparable to stages E10.5-E14.5 in mouse, stages HH19-HH30 in chick (defined by Hamburger and Hamilton 1951) and to stages
24-48 hpf in zebrafish (reviewed in Rodríguez-Moldes 2017). From S31 to S32, key morphogenetic events take place, when the $S$. canicula telencephalon fuses at medial pallial levels and the lateral ventricles emerge. Main embryonic territories are clearly recognizable by $\mathrm{S} 31$ while the basic mature structure of the telencephalon is progressively achieved from S32 on (Quintana-Urzainqui et al. 2015). In the present study, we have analysed the pallium of embryos from S29 to S32 using the expression of different neurogenic markers.

\section{Early stages of development: characterization of pallial progenitor cells}

In the telencephalon of S. canicula, S28 and S29 can be considered early neurogenic stages (Quintana-Urzainqui et al. 2015). In this study, we chose S29 as the representative stage of this period, during which the telencephalon is broadly subdivided into a pallial domain and a subpallial domain on the basis of the complementary expression pattern of Pax6 and GAD65/67 (Carrera et al. 2008; FerreiroGalve et al. 2008; Quintana-Urzainqui et al. 2015). At this stage, the cytoarchitecture of the pallium is neuroepithelial (Fig. 1) and pallial subterritories are not yet recognizable (Fig. 1a). We used various cell markers with the aim of characterizing radial glial progenitors within the pallium. Sox 2 has been used as a marker of stem cells and pluripotency (Hagey and Muhr 2014; Shimozaki 2014; Zhang and Cui 2014). In situ hybridization for ScSox2 showed that it is expressed across the entire telencephalic walls (Fig. 1b). Immunohistochemistry against the proliferating marker PCNA was also observed throughout the whole telencephalon. Both ScSox 2 and PCNA markers seemed to expand throughout most of the thickness of the telencephalic walls (Fig. 1b', c), with the exception of some cells located at very marginal positions (arrowheads in Fig. 1b', c), probably corresponding with the first cells exiting the cell cycle. Two different morphologies have been observed in PCNA-immunoreactive (-ir) nuclei: round (mainly close to the ventricular and pial surfaces; yellow arrows in Fig. 1c) and oval (as in cells located at intermediate positions; white arrows in Fig. 1c). We then analysed the expression of glial acid fibrilar protein (GFAP), a marker of radial glial cells, which has been widely reported in radial glial progenitors during development (Malatesta et al. 2008; Malatesta and Götz 2013). GFAP immunoreactivity has been observed in radial cell processes from the ventricular to the pial surface throughout the telencephalon (Fig. 1d), as well as in endfeet-like structures at the pial surface (arrows in Fig. 1d). To investigate if GFAP-ir cells exhibit characteristics of proliferative progenitors in sharks, we analysed double immunofluorescence for GFAP and PCNA (Fig. 1e). Although GFAP 

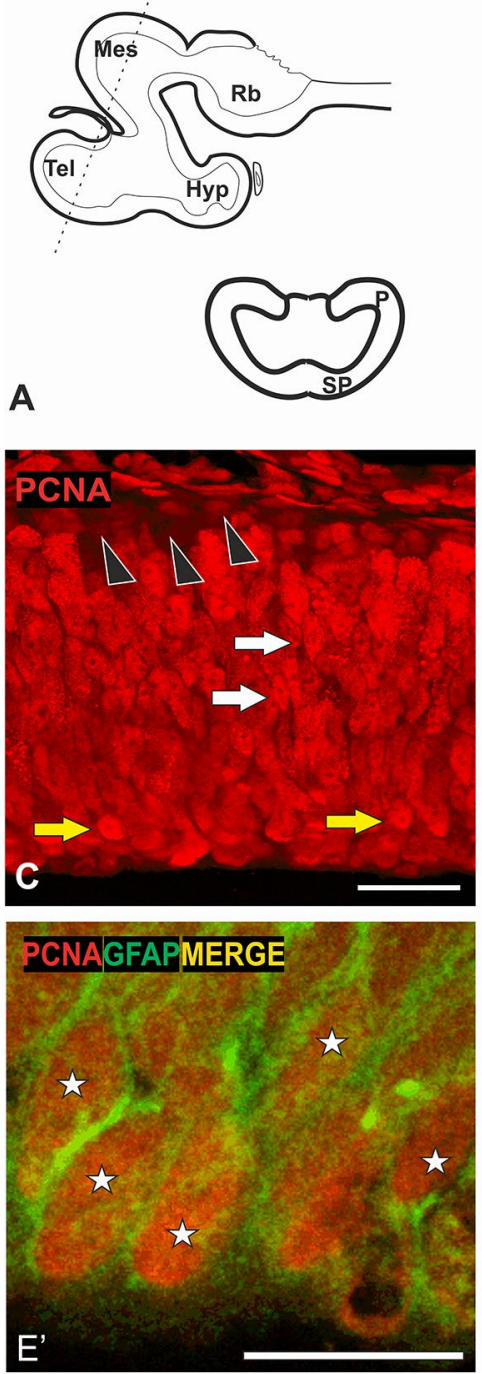
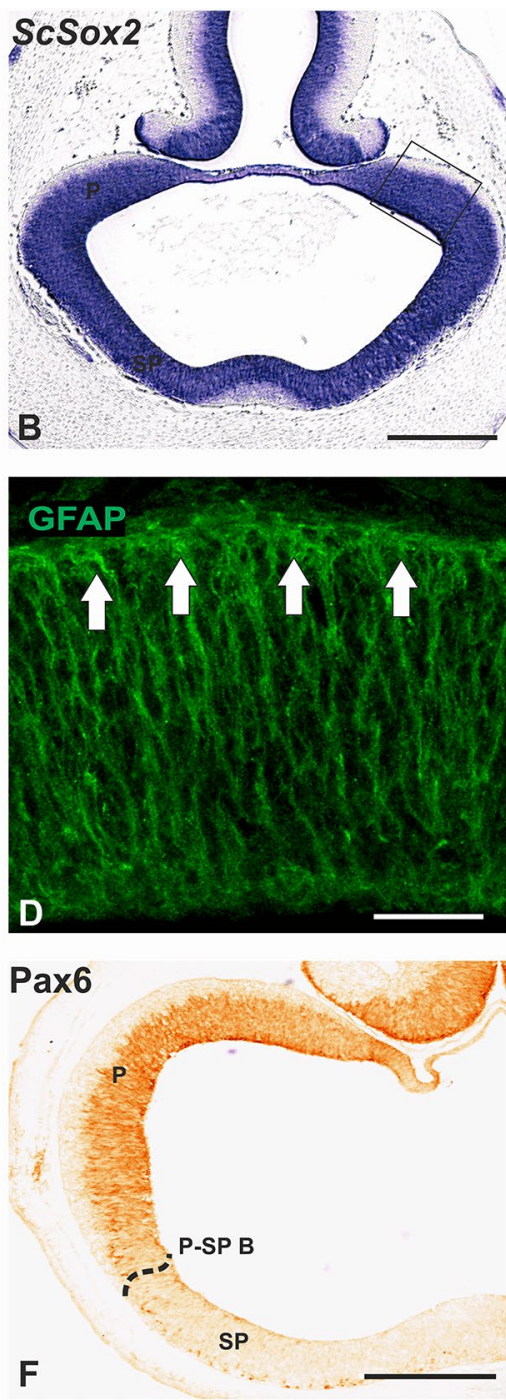
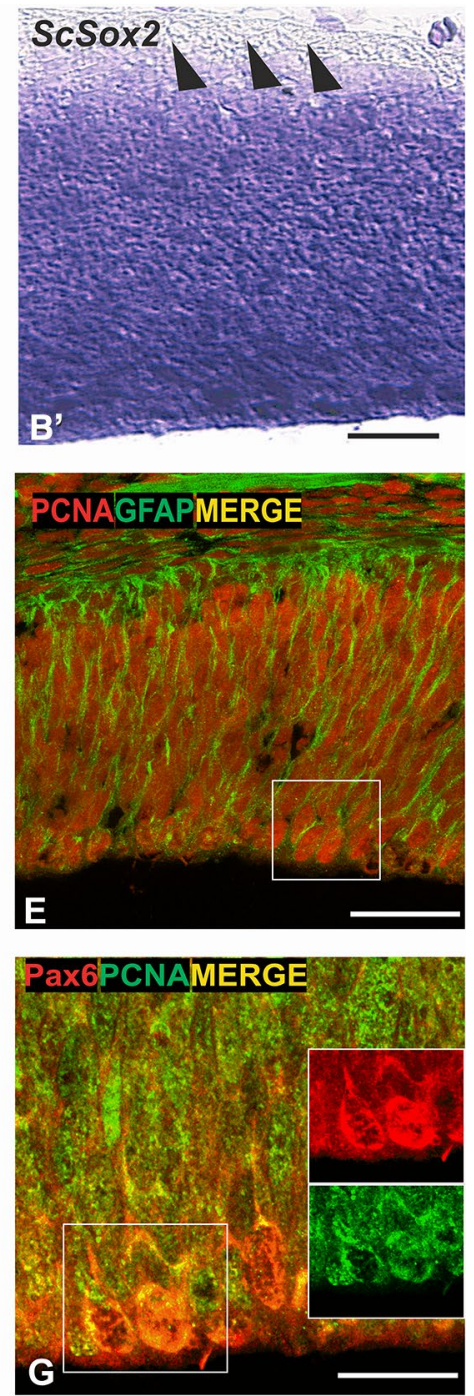

Fig. 1 Photomicrographs of transverse sections of the telencephalon of S29 of development showing the expression pattern of different progenitor cell markers. a Sagittal and transversal schemas showing gross anatomy of a S29 embryo. b, b' Transversal sections showing the expression of ScSox2 in the telencephalic wall. $\mathbf{b}^{\prime}$ Is a magnification of the region squared in $\mathbf{b}$. Black arrowheads point to cells at marginal positions that do not express ScSox2. c High magnification of the pallium showing PCNA immunoreactivity. Black arrowheads at marginal positions point to PCNA negative cells. Note the existence of two different morphologies of cells: round (yellow arrows) and oval (white arrows). d High magnification of the pallium showing radial processes stained with GFAP that reach the pial surface forming endfeet structures (arrows). e, $\mathbf{e}^{\prime}$ Double immunofluorescence for PCNA and GFAP in the pallium of $S$. canicula showing some double labelled cells (asterisks). f Panoramic view of the telencephalon of a S29 embryo showing immunoreactivity for Pax6 restricted to the pallial domain. g Double immunofluorescence for Pax6 and PCNA in the pallium of a S29 embryo showing double labelled cells. Scale bars $500 \mu \mathrm{m}(\mathbf{b}, \mathbf{f}) ; 50 \mu \mathrm{m}\left(\mathbf{b}^{\prime}, \mathbf{c}, \mathbf{d}, \mathbf{e}\right) ; 25 \mu \mathrm{m}\left(\mathbf{e}^{\prime}, \mathbf{g}\right)$

et al. 2015), was also analysed. Pax6 can be detected in the telencephalon of $S$. canicula in S29 as a band of cells restricted to the pallial domain ventricular zone (Fig. 1f). In addition, double immunofluorescence for Pax6 and PCNA revealed colocalization between both factors in pallial cells in the ventricular border (Fig. 1g).

In summary, the shark pallium at S29 expresses proliferation and pluripotency markers which expand most of the thickness of the telencephalic wall. 


\section{Pallial neurogenesis in S. canicula: exploring the existence of a SVZ in sharks}

The first signs of a zonation in the pallium were observed at S30. At this stage, ScSox 2 expression became restricted to a narrow band close to the ventricular surface, which we identified as the ventricular zone (VZ in Fig. 2a). On the other hand, DCX, a marker for newly differentiating and migrating neurons, was expressed from intermediate (weak) to marginal (strong), in what we have identified as different areas of the intermediate zone (inner intermediate zone (iIZ) and marginal intermediate zone (mIZ), Fig. 2b). A combination of ISH for ScSox 2 and immunohistochemistry for DCX can be observed in Fig. 2c showing the complementarity of their expression and how they clearly define the three areas mentioned above. In addition, double immunofluorescence for DCX and GFAP revealed DCX-ir cell bodies in the intermediate zone in close apposition to radial GFAP-ir processes (Fig. 2d, d', d", d"'). This suggests that, by S30, active radial migration occurs in the pallium of $S$. canicula.

To further characterize this intermediate zone, we have analysed proliferation by means of PCNA immunohistochemistry. PCNA immunoreactivity can still be observed covering most of the pallial territory, with the exception of some marginal portions in this territory (Fig. 3a). We observed a band of cells showing particularly intense PCNA-immunoreactivity at intermediate positions (arrows in Fig. 3a), in what it would correspond to the limit between the VZ and IZ. Since intense PCNA-ir cells (in the $S$ phase of the cycle) are committed to undergo mitosis, we suspected that actively mitotic cells might be present outside the ventricular surface, in a subventricular position. To confirm this, we performed immunohistochemistry against the mitotic marker PH3. This revealed that most mitotic cells are, as expected, located lining the ventricular surface. However, some positive cells were detected subventricularly, expanding from medial to lateral portions of the pallium, at positions compatible with the intermediate band of intense PCNA immunoreactivity (arrows in Fig. 3b).

The existence of an intermediate band of cells located at the interface between the VZ and IZ (areas defined, respectively, by ScSox 2 expression and DCX immunoreactivity), which contains proliferative and mitotically active cells, led us to consider the existence of a SVZ in the shark
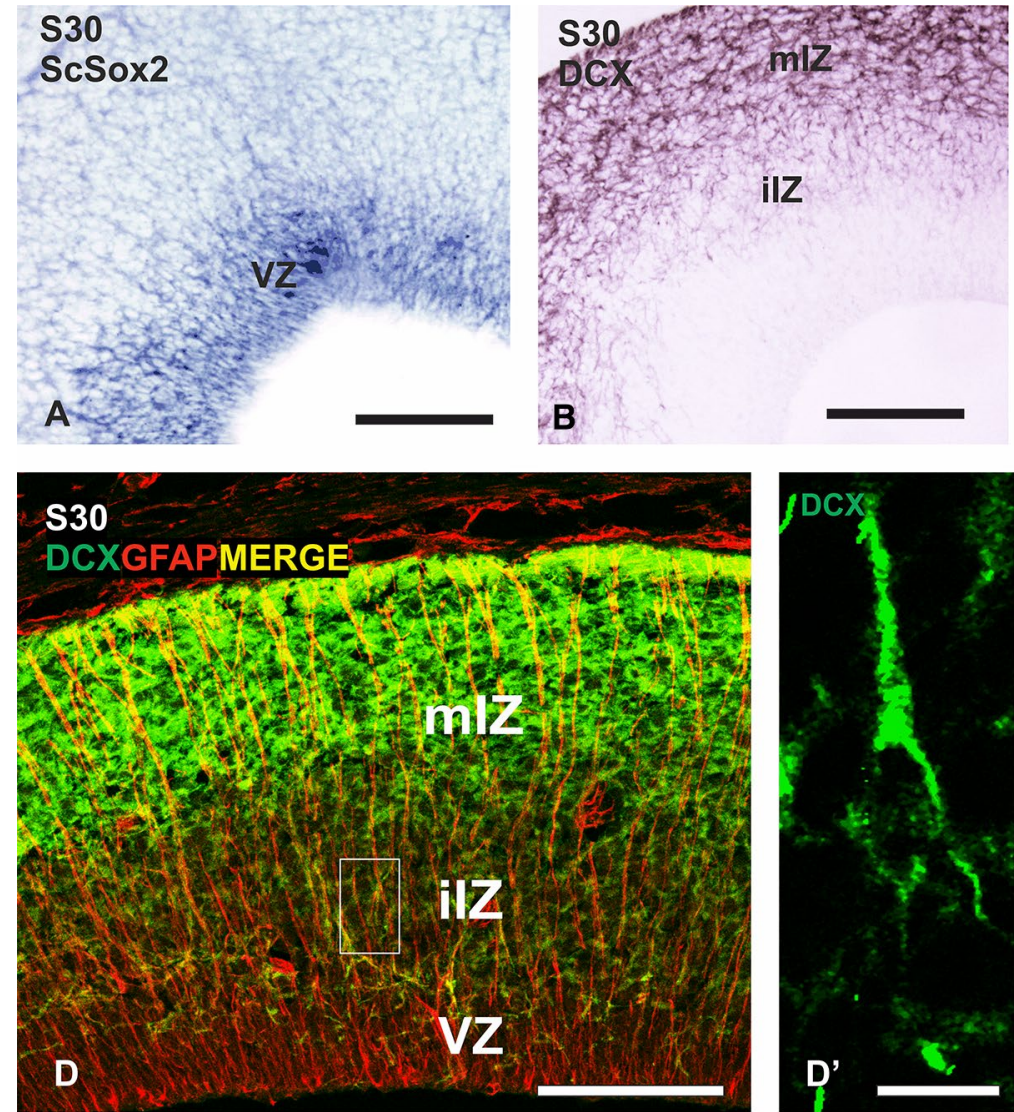

Fig. 2 Transversal sections of S30 and S31 embryos showing different neurogenic markers. a-c Transverse sections showing the differential expression of ScSox 2 and DCX in three different layers. d,
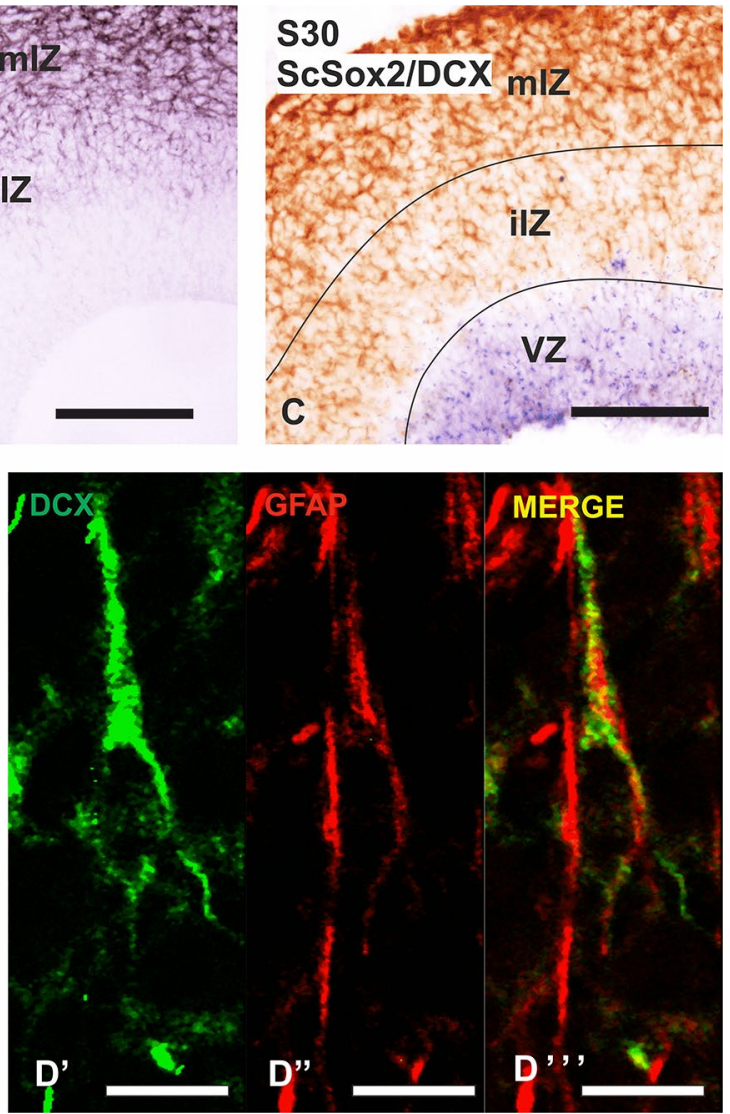

$\mathbf{d}^{\prime \prime \prime}$ Double immunofluorescence for DCX and GFAP showing DCX immunoreactive cells attached to GFAP positive cell processes in the IZ. Scale bars $200 \mu \mathrm{m}(\mathbf{a}-\mathbf{c}), 100 \mu \mathrm{m}(\mathbf{d}), 10 \mu \mathrm{m}\left(\mathbf{d}^{\prime}, \mathbf{d}^{\prime \prime}, \mathbf{d}^{\prime \prime \prime}\right)$ 
Fig. 3 Transverse sections showing the expression pattern of SVZ markers in S30 and S31. a Transverse section of a S30 embryo showing PCNA immunoreactivity in the telencephalon. Note the presence of an intermediate band of intense PCNA-immunoreactivity (arrows and box). b Transverse section of a S30 embryo showing PH3 immunoreactivity in the telencephalon. $\mathbf{c}-\mathbf{e}$ Transverse section at different magnification showing the expression pattern of ScTbr2 (c- $\left.\mathbf{c}^{\prime \prime}\right)$ and colocalization between $\mathrm{ScT}$ Tr2 and PH3 (d, e). f-h Transverse sections of the pallium of S31 embryos showing positivity for PH3, ScTbr2 and double labelled cells for both markers defining the existence of a presumptive SVZ. Scale bars $200 \mu \mathrm{m}(\mathbf{a}-\mathbf{c}, \mathbf{f}-\mathbf{h}), 100 \mu \mathrm{m}\left(\mathbf{c}^{\prime}\right)$, $50 \mu \mathrm{m}\left(\mathbf{c}^{\prime \prime}, \mathbf{d}, \mathbf{e}\right)$

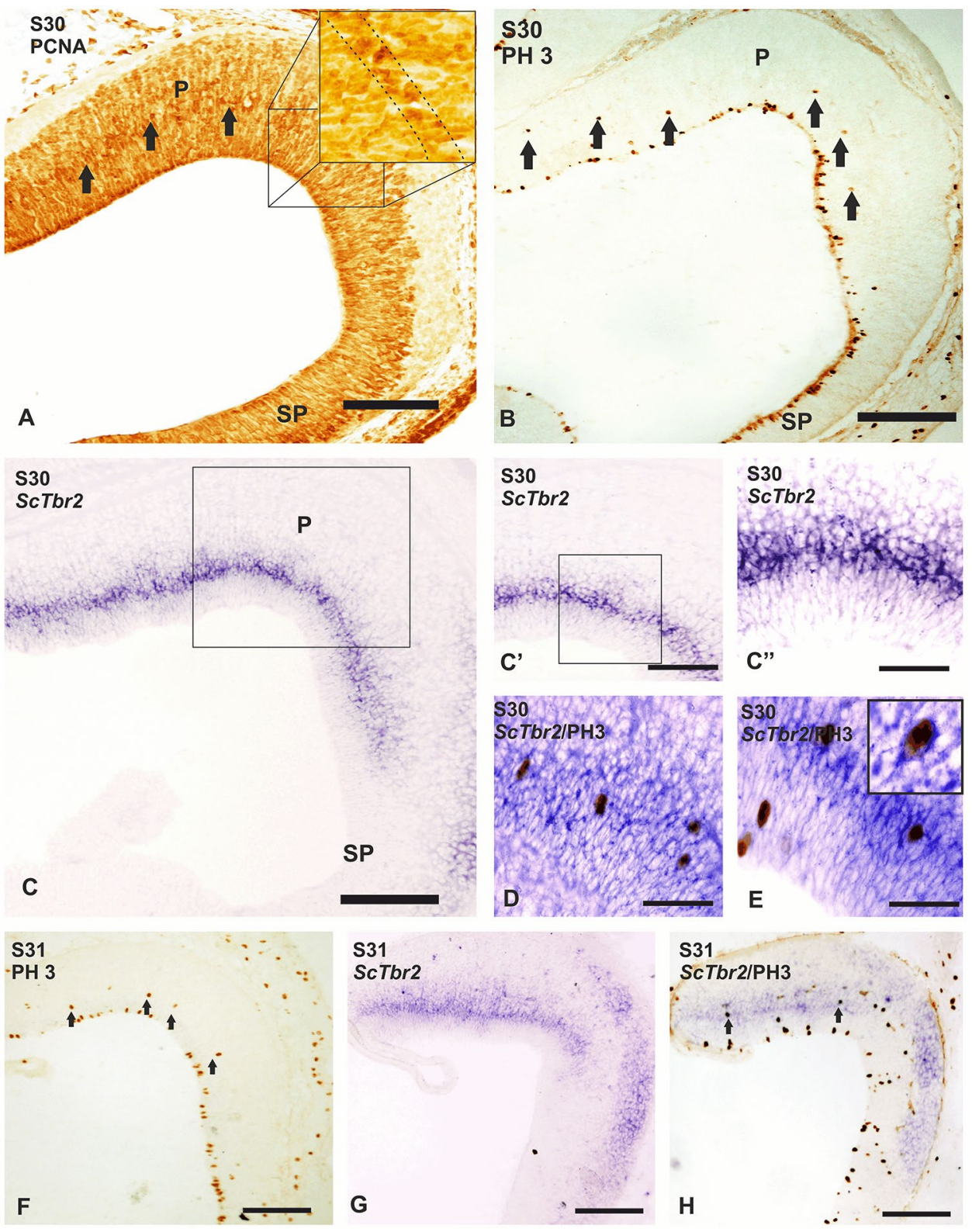

pallium. By definition (see Discussion), proliferating cells in this SVZ should be identified as IPCs. To investigate the existence of these cells, we studied the expression pattern of a well-known marker of IPCs in mammals, the transcription factor Tbr2. ScTbr2 expression was detected also as a subventricular band along the pallial domain (Fig. 3c-c"), located at the same position as both the intense PCNA-ir band and the PH3-ir subventricular cell bodies (compare Fig. 3a-c). Moreover, PH3 immunohistochemistry combined with in situ hybridization for ScTbr2 showed double labelled cells in subventricular positions (Fig. 3d, e). At S31 of development, subventricular mitoses (arrows in Fig. 3f) and the band of $S c T b r 2$ expressing cells were still very evident (Fig. 3g, h). However, the relative number of mitotic
$\mathrm{PH} 3$ positive cell bodies appeared to decrease compared to the previous stage.

To further investigate the presence of IPCs (subventricularly dividing) cells we have administered BrdU at S30 for $2.5 \mathrm{~h}$ (which becomes incorporated into DNA as it replicates in dividing cells) and then analysed BrdU incorporation at $24 \mathrm{~h}$ (S30) and 10 days (S31) after administration (Fig. 4a). Our results show that, $24 \mathrm{~h}$ post administration, BrdU-immunoreactive cells are located not only at the VZ, but also at abventricular positions (Fig. 4b, c). Similar results were found at 10 days after administration, though the number of cells containing BrdU has largely increased (Fig. 4d). Interestingly, cells showing weaker levels of BrdU are located at positions where cells undergo mitosis, i.e., at the ventricular surface and at the SVZ. Moreover, some of these weakly 

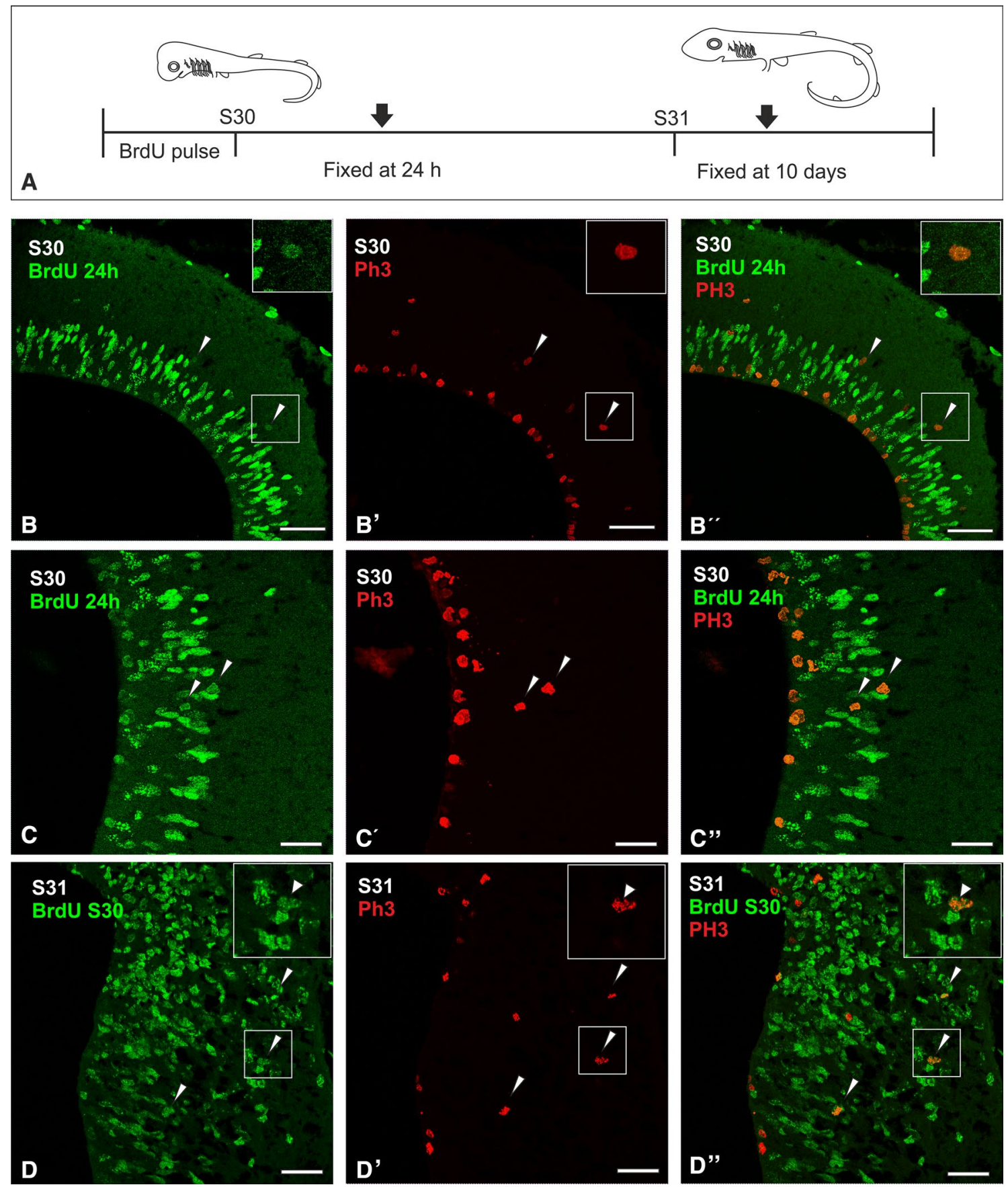

Fig. 4 Schema and transverse sections showing BrdU incorporations combined with $\mathrm{PH} 3$ in the pallium of $S$. canicula. a BrdU was administrated to embryos at S30 of development. Embryos were sacrificed at $24 \mathrm{~h} \mathrm{(S30)}$ and 10 days (S31) after BrdU incorporation. b, $\mathbf{c}^{\prime \prime}$ Transverse sections at different magnifications showing double BrdU/ PH3 labelling $24 \mathrm{~h}$ after BrdU administration. Double BrdU/PH3

BrdU-immunoreactive cells were double labelled for the mitosis marker pH3 (Fig. 4b-d").

At later stages (S32 onwards) we found no evidence of subventricular PH3-ir or ScTbr2-expressing cells (data not positive cells can be observed in subventricular positions (arrowheads). d-d" Transverse section of a S31 of development 10 days after BrdU administration showing double immunolabeled cells for BrdU and PH3 in subventricular positions (arrowheads). Scale bars: $100 \mu \mathrm{m}\left(\mathbf{d}, \mathbf{d}^{\prime}, \mathbf{d}^{\prime \prime}\right), 50 \mu \mathrm{m}\left(\mathbf{b}, \mathbf{b}^{\prime}, \mathbf{b}^{\prime \prime}, \mathbf{c}, \mathbf{c}^{\prime}, \mathbf{c}^{\prime \prime}\right)$

shown), which indicates that this subventricular population might be transitory.

The observation of a transient population of proliferative cells expressing $S c T b r 2$ and located at a subventricular 
position suggests that the shark pallium may contain basal progenitors forming a SVZ-like structure.

\section{Study of neurogenic transcription factors in S31 and S32}

S31 represents the mid developmental neurogenic period and, as it proceeds, the basic mature structure of the telencephalon is progressively acquired (Quintana-Urzainqui et al. 2015). We have taken it as reference for studying the rostral pallial subdivision since it constitutes a well-identified part of the telencephalon of $S$. canicula and it can be easily followed from S31 to S32. Since our and previous results have shown that the expression pattern of most transcription factors is highly conserved between mammals and sharks (Ferreiro-Galve et al. 2008; Rodríguez-Moldes et al. 2008, 2011, 2017; Rodríguez-Moldes 2009; Quintana-Urzainqui et al. 2015; Santos-Durán et al. 2015, 2016;
Pose-Méndez et al. 2016a, b, 2017) we have selected some neurogenic transcription factors known to be sequentially expressed during pallial neurogenesis in other vertebrates (Pax6, Tbr2, NeuroD and Tbr1) and we studied their expression in the shark pallium.

First, we studied the transcription factor Pax6 by means of immunohistochemistry. Its expression pattern was mainly found in the VZ of the pallium, which is notably narrower than at previous stages (Fig. 5a). In addition, numerous Pax6 positive cells can be found outside the ventricular layer in the presumptive dorsal pallial territory which has been already described as a divergent and distinctive trait of sharks (Ferreiro-Galve 2010; Rodríguez-Moldes et al. 2017). Right above and adjacent to the ventricular zone defined by Pax6, we observed the ScTbr2 expressing band of cells described before in a subventricular position (Fig. 5b). ScNeuroD and Tbr1-positive cells seem to occupy very similar positions (compare Fig. 5c, d), suggesting that they could
Fig. 5 Transverse sections of S31 and S32 embryos showing the expression pattern of the neurogenic markers Pax6, ScTrb2, ScNeuroD and Tbr1 in the telencephalon of $S$. canicula. a At S31, Pax6 immunoreactivity was detected in many disperse cells in the IZ of the dorsal pallium and in an intense band of cells at the $\mathrm{VZ}$ of the pallium. $S c T b r 2$ is expressed in subventricular positions of the pallium (b). ScNeuroD (c) and Tbr1 (d) were not detected in the VZ but also in the IZ. e Photomicrograph of the telencephalon of a S32 showing barely no expression of Pax6 in the VZ (arrows). In addition, ScTbr2 (F), ScNeuroD (g) and Tbr1 (h) can be observed in more marginal positions of the pallium respect to the previous stage. i Photomicrograph of the rostral telencephalon showing ScNeuroD-expression and Tbr1-immunoreactivity. $\mathbf{j}, \mathbf{j}^{\prime \prime \prime}$ Photomicrograph of the rostral telencephalon showing ScTbr2expression and Tbr1-immunoreactivity, showing double labelled cells $\left(\mathbf{j}^{\prime}\right)$ and single labelled cells for $\operatorname{ScTbr2}\left(\mathbf{j}^{\prime \prime}\right)$ and for Tbr1 ( $\left.\mathbf{j}^{\prime \prime \prime}\right)$. Scale bars $200 \mu \mathrm{m}(\mathbf{a}-\mathbf{h}), 100 \mu \mathrm{m}(\mathbf{i}, \mathbf{j})$
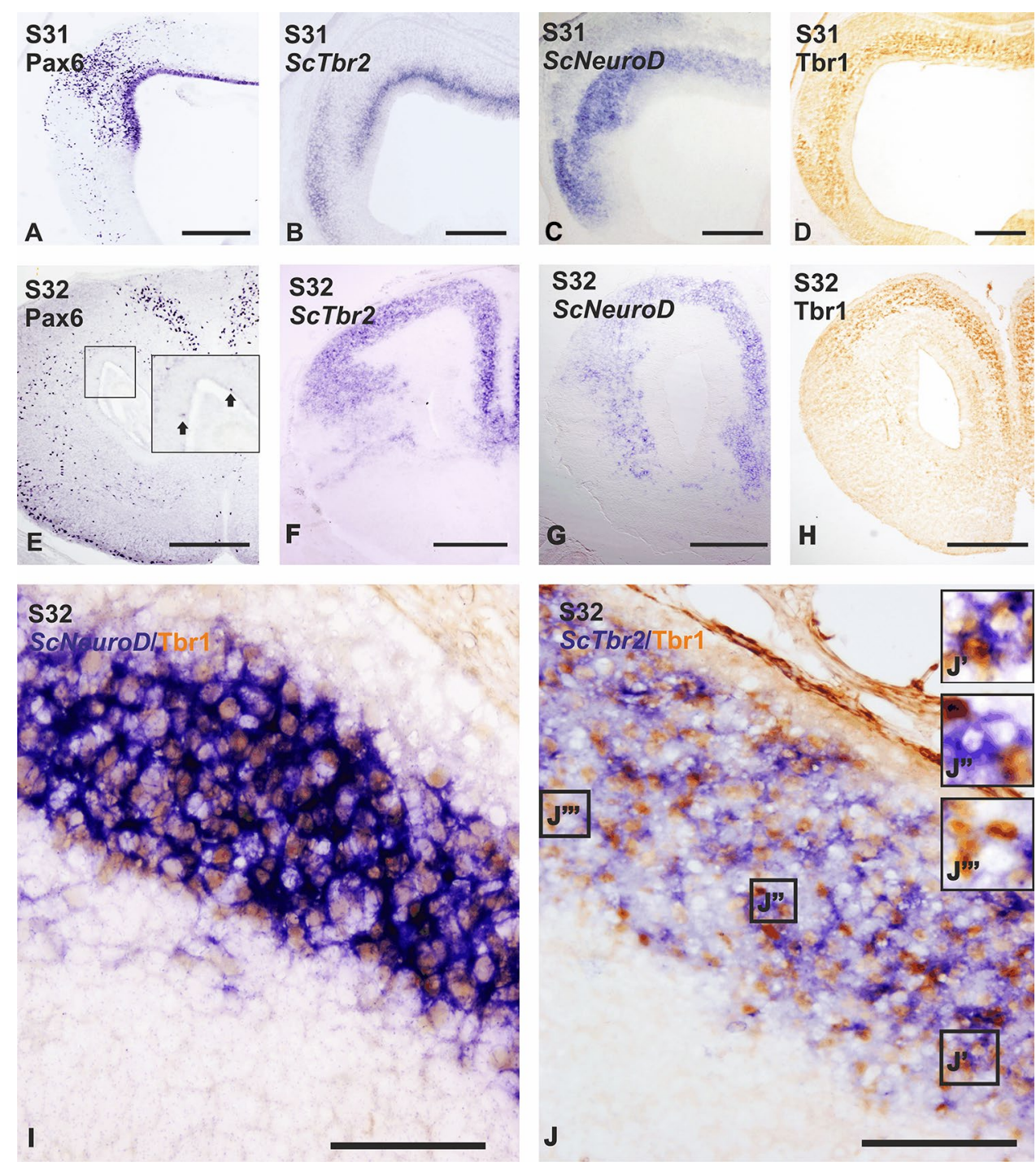
be expressed by the same population of pallial cells at $\mathrm{S} 31$. This observation holds also true at later stages (Fig. $5 \mathrm{~g}, \mathrm{~h}$ ). Although we have not determined by co-expression analysis in the same sections whether there is some extent of overlapping between $S c T b r 2$ and ScNeuroD/Tbr1-positive popula-

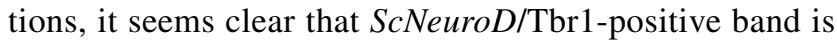
consistently thicker than the ScTbr2-positive band and that it expands further towards the intermediate pallial zone. The expression pattern of these four markers suggest that they are expressed sequentially as shark pallial progenitors exit the cell cycle, migrate radially and differentiate (first Pax6, followed by $S c T b r 2$ and finally $S c N e u r o D / T b r 1)$.

At stage 32, Pax6 immunoreactivity is no longer observed in the ventricular zone (Fig. 5e), which was already described by Ferreiro-Galve (2010). Only a few (one or two per section) Pax6 positive cells could be detected in contact with the ventricular surface (arrows in Fig. 5e). However, abundant Pax6 positive cells were observed throughout the telencephalon, specially concentrated close to the midline of the pallium (Fig. 5e).

On the other hand, the transcription factors ScTbr2, ScNeuroD and Tbr1 were no longer observed close to the ventricular surface but more restricted to the marginal positions of the pallium (Fig. $5 \mathrm{f}-\mathrm{h}$ ). Contrary to what we observed at the previous stage, positive cell bodies for the three transcription factors were apparently located in the same band of cells (Fig. 5f-h). This coincidence in their distribution pattern suggest that they could be expressed by the same population. To test this, we performed double ISH-immunohistochemistry for ScTbr2-Tbr1 and ScNeu$r o D-T b r 1$. Most (if not all) neurons in this population seem to express $S c N e u r o D$ and most of them co-express Tbr1 (Fig. 5i). Only a few scattered cells expressed only Tbr1 (Fig. 5i). We detected certain degree of colocalization between $S c T b r 2$ and Tbr1-positive populations (see double labelled cells in Fig. 5 j, j'), but also many cells that expressed only one of these markers (Fig. 5j", $\left.\mathrm{j}^{\prime \prime \prime}\right)$. In summary, at stage 32, differentiated ScNeuroD-positive neurons are found in a band at more marginal positions than at stage 31 , possibly as a result of radial migration. This ScNeuroD population seems to be heterogeneous in terms of marker expression, being a mixture of Tbr1-positive, ScTbr2-positive, double Tbr1-ScTbr2-positive.

\section{Discussion}

In this work, we have investigated the neurogenic process underlying the generation of pallial neurons in the cartilaginous fish S. canicula. Cartilaginous fishes are the only taxa available to study evolution of the early vertebrate pallium since they occupy a key phylogenetic position as a monophyletic group external to all other living jawed vertebrates (gnathostomes; Coolen et al. 2009; Rodríguez-Moldes et al. 2017). Indeed, recent whole-genome analysis showed that the genome of cartilaginous fishes evolved significantly slower than that of bony vertebrates including mammals, and even slower than the genome of the "living fossil" the coelacanth (Venkatesh et al. 2014), confirming that cartilaginous fishes must have retained many characteristics of the common ancestor of jawed vertebrates, and therefore, they must be good representatives of the ancestral condition of vertebrates. Consequently, it seems that cartilaginous fishes, because of their ancient evolutionary origin, may have remained closer to the stem of vertebrates than many other more divergent and derived animal groups (like bony fishes, amphibians or birds). Supporting this hypothesis are the astonishing similarities between the shark and mammalian developing telencephalon. Although the telencephalon, specially its dorsal part, is one of the structures that underwent more changes through mammalian evolution, the developing telencephalon of sharks shows more similarities to that of mammals than those of other animal groups mentioned above. For example, sharks possess evaginated telencephalons (instead of everted, like ray-finned fishes); most tangential migratory routes of subpallial interneurons towards the pallium are very similar to those reported in mammals (Quintana-Urzainqui et al. 2015; Alzu'bi et al. 2017), while these have not been found to date in other vertebrate groups like amphibians; and all four pallial sectors have been characterized in shark embryos (Rodríguez-Moldes et al. 2017). Although the telencephalon of sharks also shows some specific (possibly derived) characteristics like the expression of Pax6 in postmitotic pallial neurons (Rodríguez-Moldes et al. 2017), they do not exhibit big divergent telencephalic fields, like the dorsal ventricular ridge (DVR) observed in birds/sauropsids.

With that in mind, we studied pallial neurogenesis in sharks with the aim of investigating to what extent this process has changed throughout gnathostome brain evolution. Are apical progenitors present in basal vertebrates as sharks? Is the SVZ an exclusive structure of mammals? Is the transcription program of pallial-born cells a conserved feature throughout evolution? These questions are discussed below.

\section{The pallium of S.canicula contains radial-glia like apical progenitors and presents radial migration like other vertebrates}

Neurons in the pallium (developing cortex in mammals) are initially generated from a pool of progenitors in the early pseudostratified epithelium and divide at the ventricular (also named apical) surface. These are called apical progenitors (or radial glial progenitors), they express Pax6 and GFAP and they extend their processes to the pial surface 
while also maintaining contact with the apical surface (Englund et al. 2005; Malatesta y Götz 2013; Götz et al. 2015). During the different phases of their cell cycle, apical progenitors undergo periodic apico-basal movements of their nuclei through a process called interkinetic nuclear migration (Sauer 1935; Götz and Huttner 2005). In this work, we describe the existence of a similar kind of progenitors in the shark pallium expressing ScSox2 and Pax6 in their nuclei and GFAP in their radial processes. PCNA immunoreactivity revealed two different nuclear morphologies: round and close to the ventricular surface versus elongated and located at various levels across the pallial wall above the ventricular surface. Round and ventricular nuclei probably correspond to progenitors in $\mathrm{M}$ phase while elongated nuclei correspond to progenitors in $\mathrm{G} 1 / \mathrm{S} / \mathrm{G} 2$ phases which typically undergo interkinetic nuclear migration (Sauer 1935; Götz and Huttner 2005). These observations support the existence of apical progenitors in sharks exhibiting the main features of radial glial precursors.

Developmental studies show the presence of apical progenitors/radial glial cells during the development of the central nervous system of turtles (Clinton et al. 2014; MartínezCerdeño et al. 2016), amphibians (Moreno and González 2017) and teleosts (Wulliman and Puelles 1999; Wulliman and; Knipp 2000; Wulliman and; Rink 2002; Lyons et al. 2003; Mueller and Wulliman 2003; Alexandre et al. 2010), that would act as neural progenitor cells. The fact that radial glial progenitors are present in the developing brain of sharks and in other species of vertebrates suggests that they are an ancient trait of vertebrates that has been highly conserved along vertebrate evolution. Therefore, we can conclude that apical/radial glial-like progenitors appeared very early in evolution. Unfortunately, there are no developmental studies available in lampreys that pointed to the existence of radial glial progenitors in this vertebrate group (positioned at the base of vertebrate evolution), which prevents us from assessing if the emergence of radial glial progenitors occurred at the transition from agnathans to jawed vertebrates or even earlier in evolution.

At a certain point in development of the mammalian pallium, some cells in the highly proliferative pseudostratified epithelium begin to exit the cell cycle and migrate radially along the processes of the radial glial progenitors (Corbin et al. 2001; Campbell and Götz 2003; Götz and Huttner 2005; Kosodo and Huttner 2009; Rakic 2009; Aboitiz 2011). Eventually, they stop their radial movement and adopt a new position in the developing pallium away from the ventricular surface, what give rise to the formation a stratified structure. Cells still cycling (progenitors) remain in contact with the ventricular surface constituting the ventricular zone (VZ). Radially migrating cells and new settled neurons form the intermediate zone, which in turn can be subdivided in different subzones (iIZ, mIZ). In this study, we have observed the formation of this basic zonation in embryos of $S$. canicula by stage S30. The shark ventricular zone expressed proliferating (PCNA and PH3), stem cell (ScSox2) and pallial progenitor markers (Pax6) while intermediate zone expressed markers of postmitotic and newly generated neurons like DCX or ScNeuroD. In addition, we observed DCX-positive cell bodies outside the VZ and closely apposed to GFAPpositive radial processes. We interpret those cells as newly generated neurons migrating along the radial processes of apical progenitors, indicating that in the shark pallium the process of radial migration takes place in a similar way to that described in other vertebrates. Radial migration was thought to be a unique trait in mammals and birds (Hatten 2002). However, recent studies in different species of vertebrates clearly revealed that it is also a highly conserved trait of other vertebrates (zebrafish: Mueller et al. 2011; amphibians; Moreno and González 2017; reptiles; Montiel et al. 2015). Our observations in sharks support this idea. However, whether radial migration appeared before the emergence of jawed vertebrates is still unknown. Studies in the adult brain of lampreys and mixins have revealed radial glia-like cells (ependymoglia), immunoreactive to anti-GFAP antibodies in mixins and to anti-citokeratin antibodies in lampreys (Wicht et al. 1994; Merrick et al. 1995; Nieuwenhuys and Nicholson 1998). Whether they play a role in neuronal migration during embryonic development is not known. In fact, most neurons in the brain of lampreys remain close to the ventricular zone (Nieuwenhuys and Nicholson 1998) and therefore, it is possible that radial migration is not necessary in this animal group.

\section{The shark pallium contains Tbr 2 intermediate progenitors and a basic subventricular zone: evolutionary implications}

The pallial SVZ was until recently thought to appear in the transition from reptiles to mammals (Martínez-Cerdeño et al. 2006, 2016) and it has been pointed as one of the main evolutionary events leading to the high complexity of mammalian cortices (see "Introduction"). Although several studies have described the existence of subventricular zones in other vertebrates (Montiel et al. 2015), very few observed them in the dorsal pallium, which is the homologous territory to the mammalian developing cortex (reviewed by Medina and Abellán 2009).

But, what defines a pallial SVZ? In 1970, the Boulder Committee Report defined it as a zone located at the junction between the ventricular and intermediate zones, containing round or oval cells distinguished from young neurons of the intermediate zone by their proliferative activity and the lack of interkinetic nuclear migration during the cell cycle. These 
neurons come to position soon after the intermediate zone begins to form (Angevine et al. 1970). Other two criteria have been incorporated in the last decades. It is now widely accepted that the subventricular zone contains intermediate progenitors. Unlike apical progenitors, basal (intermediate) progenitors are characterized by their subventricular position (away from the ventricular surface) and they do not undergo interkinetic nuclear migration (Götz and Huttner 2005; Martínez-Cerdeño et al. 2016). Intermediate progenitors are also characterized by their differential gene expression, typically expressing the non-coding RNA Svet1 and the genes that encode the transcription factors Tbr2, Cux1 and Cux2 (Englund et al. 2005; Götz and Huttner 2005 and references therein; Hevner et al. 2006). The presence of the transcription factor $\mathrm{Tbr} 2$ has been proposed as a criterion to identify SVZ cells and define the boundaries of the SVZ itself (Martínez-Cerdeño et al. 2016). Besides, Tbr2 is transiently expressed in cortical SVZ progenitor cells (Arnold et al. 2008; Martínez-Cerdeño et al. 2016). Therefore, a well-defined pallial SVZ must satisfy at least the following criteria: (1) subventricular position throughout the area of the dorsal cortex, (2) presence of mitotically active cells (3) presence of Tbr2-expressing cells dividing at this location that (4) are transiently found during development. According to the above criterion, a clearly defined and organized SVZ has been observed in the ventral telencephalon of birds (subpallium) and some regions of the pallium like the dorsal ventricular ridge (DVR) (Cheung et al. 2007; Montiel et al. 2015). However, its presence in the hyperpallium, which is considered by most as the homologous of the developing cortex of mammals (reviewed by Medina and Abellán 2009), is still a matter of debate (Striedter and Keefer 2000; Martínez-Cerdeño et al. 2006; Striedter and Charvet 2008; Charvet and Stiedter 2009; Charvet et al. 2009; Montiel et al. 2015; Martínez-Cerdeño et al. 2016). The first study concerning the existence of a SVZ in the pallium of birds dates from 1999, where Bulfone et al. (1999) found Tbr2 positive cells organized subventricularly in a $\mathrm{HH} 28$ chicken. However, neither their proliferation status nor their exact position within the pallium were specified. Nomura et al. (2016) recently demonstrated the existence of different types of basal progenitors in the chicken pallium and that some of them did not express Tbr2. In this work, the authors proposed that all intermediate progenitors (both Tbr2-positive and negative) could derive from a primitive population of scattered abventricular mitotic cells that might be already present in ancestral amniotes (Nomura et al. 2016).

Turtles have been pointed as the most closely related living animal to the common ancestor of mammals and reptiles (Goffinet 1983; Nieuwenhuys 1994). Studies in Trachemys scripta elegans, a species of turtle, reported a very similar scenario than the one described in birds by Montiel et al.
(2015), presenting an anatomically defined SVZ in the DVR but not in the dorsal cortex homologous region (MartínezCerdeño et al. 2006; 2016). It is important to highlight that both, birds and turtles exhibit clear expression of Tbr 2 in the hyperpallium/dorsal pallium, however, these Tbr2-positive cells are not clustered in a subventricular position but scattered through the ventricular zone. All evidences to date point to the lack of a SVZ in the pallium of other reptiles (Charvet et al. 2009; Martínez-Cerdeño et al. 2016).

In amphibians, very recent work from Moreno and González (2017) explored the existence of a pallial SVZ in a detailed study of Xenopus pallial neurogenesis. They detected clusters of Tbr2-positive cells away from the ventricular zone (especially in the ventral pallium) and some scarce abventricular mitoses. However, they reported that all Tbr2 pallial neurons were postmitotic and the occasional PH3-positive mitotic cells did not express Tbr2. Concerning teleost fishes, Mueller et al. (2008) described the existence of Tbr 2 cells in the pallium of developing zebrafish as a tier of cells close or within the ventricular zone (see also Wullimann 2009; Mueller and Wulliman 2016). Unfortunately, the lack of further characterization precludes a clear identification of these cells as potential intermediate progenitors in bony fishes.

Most of the evolutionary hypotheses derived from the studies mentioned above consider that the first intermediate progenitors expressing Tbr2 in an organized and anatomically defined SVZ appeared during mammalian evolution (Cheung et al. 2007, 2010; Montiel et al. 2015). They postulate that the SVZ might have represented a key evolutionary milestone leading to the emergence of a 6-layered cortex. Other authors proposed that pallial SVZ and basal progenitors might have appeared independently in birds and mammals leading to the emergence of different basal progenitor modalities in these animal groups (Charvet et al. 2009; Nomura et al. 2016). As far as we are concerned, Martínez-Cerdeño et al. (2016) were the only authors so far postulating an earlier origin for Tbr2-related SVZ in the common ancestor of mammals and sauropsids. They based their conclusions on a comparative study in two species of birds (chick and dove), a species of lizard and a species of turtle. Contrary to other studies in birds, they reported a subventricular band of Tbr2-positive cells in the hyperpallium (dorsal cortex homolog). Unfortunately, whether these cells expressed mitotic markers was not specified. Very few studies considered the scenario in anamniotes, suggesting that intermediate progenitors might be present in a primitive form, mainly as scattered abventricular mitoses that do not express Tbr2 (Moreno and González 2017).

Thus, the current view about pallial SVZ evolution to date hypothesizes that the first abventricular mitoses appeared at some point during anamniote evolution (probably anterior 
to a tetrapod ancestor) representing the first step and primitive form of basal progenitors and that only mammals, and perhaps some birds, secondarily acquired higher complexity in their organization accompanied by the expression of Tbr2related genetic program. These considerations were mainly based on observations in Xenopus where no double labelled Tbr2-PH3 have been reported so far (Moreno and González 2017). However, information about non-tetrapod vertebrates was lacking.

In this work, we present evidence of the existence of an anatomically defined SVZ in the pallium of sharks. First, we identified the interface between the VZ and IZ (areas defined, respectively, by ScSox 2 expression and DCX immunoreactivity). Second, we observed proliferating, mitotically active ( $\mathrm{PH} 3$ positive) band of neurons at a subventricular position aligned parallel to the ventricular surface. Third, this band of neurons strongly expresses $S c T b r 2$ and colocalization between PH 3 and ScTbr 2 was confirmed. Importantly, this population of cells has been observed at all medio-lateral levels of the developing pallium, including, therefore, the potential dorsal pallium (see Figs. 3, 5, present work). BrdU assays have been additionally used to investigate proliferation behaviour of cells dividing in this band. Dividing cells incorporate BrdU during the S-phase of the cell cycle. BrdU detection reveals where these dividing cells (or their daughters) are located at the time of fixation. When embryos are fixed after $24 \mathrm{~h}$, cells that undergo an only mitosis after BrdU incorporation retain high levels of BrdU while dividing cells dilute the incorporated BrdU by a factor of two with each cell division (see Stiedter 2015). Under this rationale, in short time windows, weaker levels of BrdU indicate when progenitors have divided, at least once (therefore, weaker levels can be correlated to higher proliferation rates). In our hands, weaker BrdU levels were present either at the VZ (where apical progenitors are found, mitosis occurring at the ventricle) or at the SVZ (where basal, intermediate progenitors are found, mitosis occurring subventricularly since they do not undergo interkinetic nuclear migration; see above). Moreover, the mitotic marker PH3 was found in weakly BrdU-immunoreactive cells at these locations even when fixed 10 days after BrdU incorporation, which indicates that these progenitors are still capable of cell division.

Finally, in agreement with the Boulder Committee Report description (Angevine 1970), we observed that these cells are placed right after the ventricular and intermediate zones are formed (S30 in S. canicula). This population is very evident at S30 and S31 of development (equivalent to stages E13.5 and E14.5 in mouse approximately) and it disappears by S32, when the basic mature morphology of the shark brain is achieved and Pax6 associated ventricular proliferation seems to cease (Ferreiro-Galve 2010; Quintana-Urzainqui et al. 2015; Rodríguez-Moldes et al. 2017 and present results). The transient nature of these type of cells also fits with the description of the SVZ dynamics in mammals (Arnold et al. 2008). Moreover, it has been described that the SVZ serves as a route of migration for GABAergic neurons originated in the subpallium and migrating through the pallium during development (Del Rio et al. 1992; reviewed in Montiel et al. 2015). This kind of tangential migration was recently identified in shark embryos by $S c D l x 2$ and GAD expression analysis. The position of the $\mathrm{ScT} \mathrm{Tb} 2$ and $\mathrm{PH} 3$-positive nuclei described in the present work fits precisely the position of the stream of tangentially migrating cells throughout the pallium described by QuintanaUrzainqui et al. (2015). However, the quantity of mitotic cells found at this subventricular position seemed to be much lower than in mammals. It seems plausible that what we are observing in the brain of S. canicula are the first steps towards the formation of intermediate progenitors organized in a defined zone in the pallium of vertebrates. Sharks and skates represent a significant step in pallial organization when compared to agnathans such as the lamprey (the only extant vertebrate with a more ancient origin than sharks). The pallium of lampreys is simpler and significantly smaller when compared to the shark pallium (Pombal et al. 2011). Cartilaginous fishes are the first vertebrates to develop evaginated palliums with clear and big ventricles. It is conceivable that the expansion of the pallium in sharks with respect to lampreys might be due to the appearance of a new type of amplifying progenitor. However, the existence of intermediate progenitors in more ancient vertebrates (lampreys) remains to be explored. A summary of all the available data about the existence of a SVZ in the dorsal pallium along the scale of vertebrates is represented in Fig. 5.

Our observations led us to propose that basal progenitors exhibiting the basic features of a SVZ, including the expression of the basal progenitor marker Tbr2, might have been already present in the common ancestor of mammals and cartilaginous fishes, that is, in the common ancestor of all gnathostomes. There is no doubt that the increase in complexity of the pallial SVZ across different mammals (including the appearance of different types of basal progenitors and the compartmentalization in an inner and outer SVZ) correlates with increasing complexity in mammalian cortices. Nevertheless, we propose here that the existence of a basic pallial SVZ with all its components can be traced back to the origin of all jawed vertebrates. Consequently, we do not contemplate intermediate progenitors and their genetic program of specification (Tbr2-related) as a novelty of mammals or even amniotes but the ancestral condition of pallial neurogenesis in vertebrates. We also postulate that the evolutionary appearance of basal progenitors might have been crucial for the first big increase in size of the pallium (in cartilaginous fishes, the telencephalon represent the 50\% 
Fig. 6 Summary of published data about the existence of a SVZ in the dorsal pallia subdivision along the scale of vertebrates

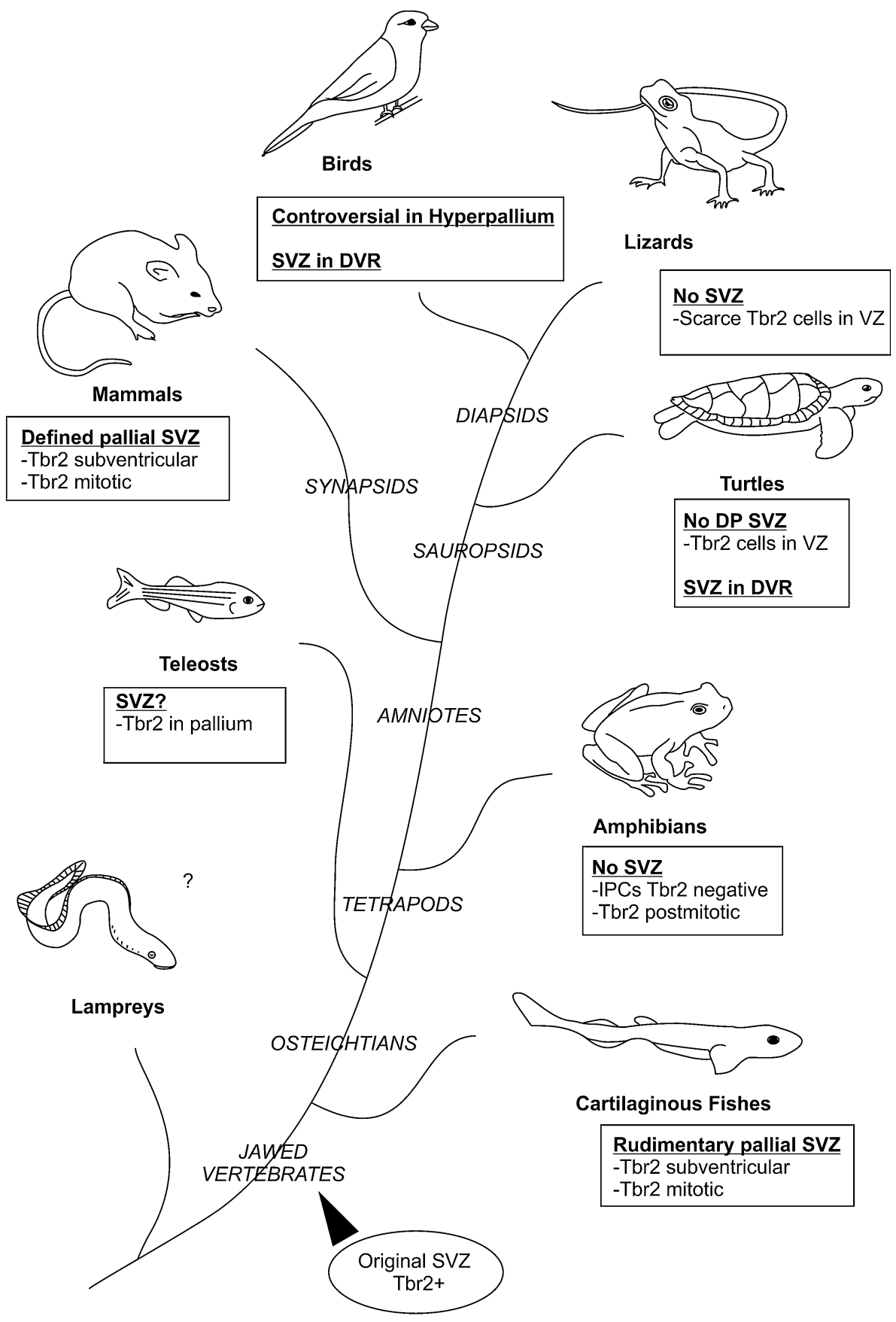

of the size of the encephalon; Yopak et al. 2015). In the light of our results, we postulate a scenario in which basal progenitors expressing Tbr2 appeared in the common ancestor of all gnathostomes and were secondary lost in many groups of vertebrates (see Fig. 6). The functional reasons and structural consequences of this potential loss remain to be explored.

\section{Sequence of transcription factor expression in pallial cells: comparison with other vertebrates}

During development, the mammalian cortex glutamatergic cells, represented by pyramidal cells, are born locally from radial glial and Pax6-expressing progenitor cells located in the ventricular zone of the pallium (Englund et al. 2005). As new-born neurons differentiate and migrate radially to their final destination in the cortex, they successively express a well-established sequence of transcription factors, namely 
Tbr2, NeuroD and Tbr1 (reviewed by Hevner et al. 2006). These factors show a partially overlapping expression pattern that perfectly differentiates the VZ (Pax6), SVZ (Tbr2), IZ (NeuroD) and cortical plate (CP) (Tbr1) in the mouse developing cortex. Despite the exact role of these transcription factors is not well understood, it is accepted that they are part of the transcriptional program that establishes the glutamatergic phenotype (Englund et al. 2005; Abdel-Mannan et al. 2008; Roybon et al. 2009; Boutin et al. 2010).

Despite this sequence of factors has not been studied in the analogous cortex of sauropsids, Tbr2 and Tbr1 expression has been studied in birds (Cheung et al. 2007; MartínezCerdeño et al. 2016; Nomura et al. 2016) and Tbr2 in reptiles (Clinton et al. 2014; Martínez-Cerdeño et al. 2016). Tbr2 expression, both in birds and reptiles, has been observed in ventricular or subventricular positions, and a marginal band of Tbr1 in birds, which is highly coincident with the expression pattern in the mammalian cortex. On the other hand, as far as we know, there are no studies concerning NeuroD in the developing telencephalon of this species. In amphibians (Xenopus), some studies have detected Tbr2, NeuroD and Tbr1 expression in postmitotic neurons in the developing/juvenile pallium (D'Amico et al. 2013; Moreno and González 2017). However, up to date, the expression of this factors in Xenopus has not been analyzed together. In teleost fishes, the expression of Pax6, the T-box transcription factors and NeuroD have been studied during development and larvae stages in zebrafish (Mione et al. 2001; Wullimann and Rink 2001, 2002; Mueller and Wullimann 2003; Mueller et al. 2008; Wullimann 2009; Mueller and Wulliman 2016). These studies suggest that a rather similar neurogenic sequence to that found in mammals might be present in the developing pallium of zebrafish, except for the absence of a Pax6 expression domain in the ventricular proliferative layer in this species (Wullimann and Rink 2001).

Here, we present full evidence that the transcription factors involved in the development of pallial-born neurons in mammals are present in sharks in analogous stages of development. At S31 Pax6 immunoreactivity was detected in the ventricular zone while $S c T b r 2$, ScNeuroD and Tbr1 codistribute in a subventricular band. However, ScTbr2 positive cells are located closer to the VZ compared to $S c N e u r o D$ or Tbr1 positive cells, which show overlapping expression patterns. At S32, ScTbr2 expression close to the VZ of the dorsal pallium disappears and it is now observed in more marginal positions. In the same way, ScNeuroD and Tbr1 are detected closer to the pial surface, suggesting a radial migration of these cells, though the emergence of ScTbr2-, ScNeuroD and Tbr1-expressing cells at marginal positions cannot be discarded. The expression pattern of these four transcription factors has been summarized in in Fig. 7. The expression pattern of these markers is a conserved feature of many glutamatergic neurons in the mammalian brain like in the cortex, olfactory bulb, hippocampus or cerebellum, both during development and, concerning the hippocampus, in adult neurogenesis (Englund et al. 2005; Hevner et al. 2006; Hodge et al. 2012; Imamura and Greer 2013; Bond et al. 2015). Here, we show that these markers are conserved along evolution at least in the pallial structure, concluding that the main molecular machinery/ transcriptional program that gives rise to pallial-born neurons is an ancestral condition of vertebrates. Whether they are conserved in other brain areas in sharks is unknown.

The fact that Pax6 and ScTbr2 are present in the VZ and SVZ, respectively, is similar to that reported in mammals. However, we found that ScTbr2, ScNeuroD and Tbr1 codistribute in many cells in the same territory (present results). This suggest that, despite in sharks apical progenitors (Pax6) and newborn neuroblasts are clearly differentiated, $\mathrm{ScT}$ Tr2, ScNeuroD and Tbr1 cell populations do not show a zonal distribution pattern similar to that observed in mammals. In addition, Tbr2 and Tbr1 do not colocalize in the cortex of mammals, contrary to what we have found in the pallium of S. canicula, suggesting that the expression of Tbr2-NeuroDTbr1 do not take place as sequentially as in mammals, but rather overlapped. This scenario is similar to that found with mitral cells in the olfactory bulb of mammals, where Tbr2
Fig. 7 Schema of the development of pallial born neurons in the developing pallium of $S$. canicula

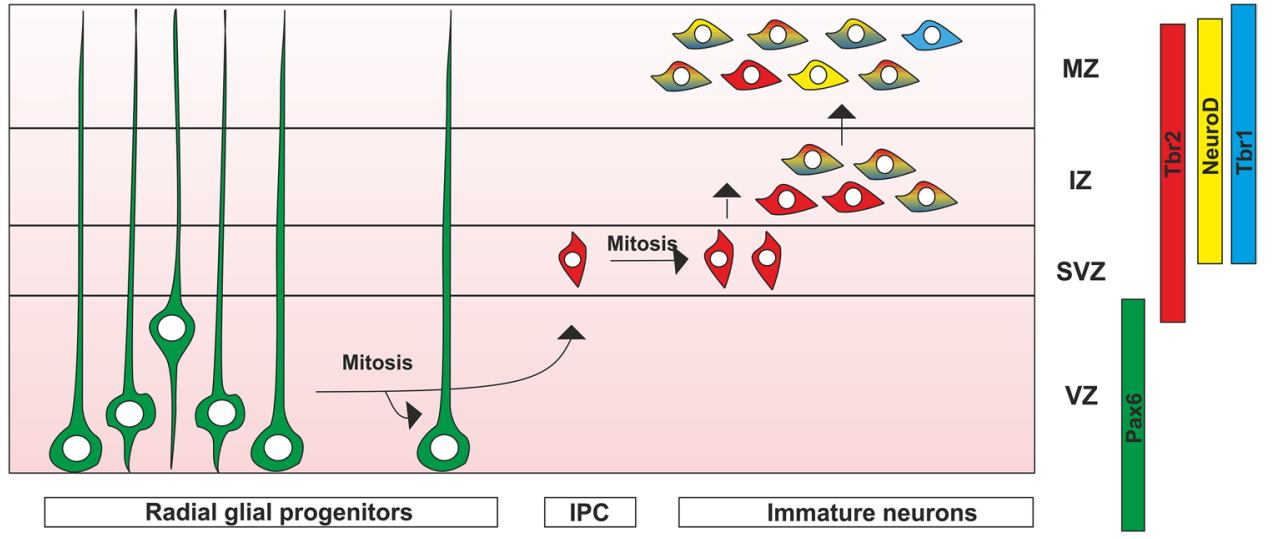


and Tbr1 double labeled cells can be found (Imamura and Greer 2013).

It has been suggested that the segregation of transcription factors in zones in mammals might be related to layer-related fate specification (Hevner et al. 2006). In addition, cortical layering in mammals is also controlled by a subset of marginal/subpial neurons called Cajal-Retzius cells (C-R). These cells secrete signaling molecules like Reelin, an extracellular matrix glycoprotein, related with the formation of cortical layers (Hevner et al. 2003; D'Arcangelo 2006). C-R cells have been found in species with layered cortices (reptiles: Goffinet et al. 1999; Tissir et al. 2003; Cabrera-Socorro et al. 2007; birds; Bernier et al. 2000; mammals:). Interestingly, in the developing pallium of $S$ canicula a marginal population positive to Reelin has been found during the neurogenic period (Quintana-Urzainqui et al. 2015). Whether they are similar to $\mathrm{C}-\mathrm{R}$ cells needs further investigation. If that is the case, the lack of segregation of transcription factors in the pallium of $S$. canicula and the absence of layering in the adult would support the hypothesis that C-Rdependent layering might need a previous segregation of transcription factors in zones.

Our results clearly suggest that the main machinery of transcription factor orchestrating neurogenesis of pallialborn neurons in mammals is present in sharks. However, as depicted above, a clear segregation in layers (VZ; SVZ; IZ; $\mathrm{CP}$ ) of all the transcription factors as the one observed in mammals, is not found in S. canicula, which might result in cytoarchitectonic organization differences between the pallium of mammals and fishes.

\section{Conclusions}

In this work, we describe the presence of the main two types of pallial progenitors (apical and basal) in the telencephalon of sharks as well as the existence of a rudimentary pallial SVZ. The evolutionary implications of this observation are not trivial, moving the hypothetical origin of this structure back to the common ancestor of all jawed vertebrates. We also report that the main transcriptional program specifying the glutamatergic lineage in the pallium (Pax6, Tbr2, NeuroD, Tbr1) was already present in cartilaginous fishes. However, the segregation of these transcription factors in different cell populations was not observed at later stages of embryonic development indicating that this non-zonal distribution pattern might be the ancestral condition that lead to a non-laminated pallium.

Comparative studies are a powerful tool to address evolutionary changes. Studying a basal jawed vertebrate like $S$. canicula has proven to be very useful, especially in regard to the development and evolution of the telencephalon. Insights in this field contribute to our knowledge of basic mechanisms of neurogenesis and ultimately will help to unveil how our brains evolved.

Acknowledgements This work was supported by the Spanish Ministerio de Economía y Competitividad-FEDER (BFU2014-5863-1P).

\section{Compliance with ethical standards}

Conflict of interest The authors declare that they have no conflict of interest.

Ethical approval All procedures conformed to the guidelines established by the European Communities Council Directive of $22 \mathrm{Sep}-$ tember 2010 (2010/63/UE) and by Spanish Royal Decree 53/2013 for animal experimentation and were approved by the Ethics Committee of the University of Santiago de Compostela.

Open Access This article is distributed under the terms of the Creative Commons Attribution 4.0 International License (http://creativeco mmons.org/licenses/by/4.0/), which permits unrestricted use, distribution, and reproduction in any medium, provided you give appropriate credit to the original author(s) and the source, provide a link to the Creative Commons license, and indicate if changes were made.

\section{References}

Abdel-Mannan O, Cheung AF, Mölnár Z (2008) Evolution of cortical neurogenesis. Brain Res Bull 75:398-404

Aboitiz F (2011) Genetic and developmental homology in amniote brains. Toward conciliating radical views of brain evolution. Brain Res Bull 84:125-136

Alexandre P, Reugels AM, Barker D, Blanc E, Clarke JD (2010) Neurons derive from the more apical daughter in asymmetric divisions in the zebrafish neural tube. Nat Neurosci 13:673-679

Alzu'bi A, Lindsay S, Kerwin J, Looi SJ, Khalil F, Clowry GJ (2017) Distinct cortical and sub-cortical neurogenic domains for GABAergic interneuron precursor transcription factors NKX2.1, OLIG2 and COUP-TFII in early fetal human telencephalon. Brain Struct Funct 222:2309-2328

Angevine JB, Bodian D, Coulombre AJ, Edds MV, Hamburger V, Jacobson M, Lyser KM, Prestige MC, Sidman RL, Varon S, Weiss PA (1970) Embryonic vertebrate central nervous system: revised terminology. Anat Rec 166:257-261

Anthony TE, Heintz N (2008) Genetic lineage tracing defines distinct neurogenic and gliogenic stages of ventral telencephalic radial glial development. Neural Dev 3:30

Arnold SJ, Huang GJ, Cheung AF, Era T, Nishikawa S, Bikoff EK, Molnár Z, Robertson EJ, Groszer M (2008) The T-box transcription factor Eomes/Tbr2 regulates neurogenesis in the cortical subventricular zone. Genes Dev 22:2479-2484

Ballard WW, Mellinger J, Lechenault (1993) A series of normal stages for development of Scyliorhinus canicula, the lesser spotted dogfish (Chondrichthyes: Scyliorhinidae). J exp zoo 267:318-336

Ballout N, Frappé I, Péron S, Jaber M, Zibara K, Gaillard A (2016) Development and maturation of embryonic cortical neurons grafted into the damaged adult motor cortex. Front Neural Circuits 10:55

Bernier B, Bar I, D’Arcangelo G, Curran T, Goffinet AM (2000) Reelin mRNA expression during embryonic brain development in the chick. J Comp Neurol 422:448-463 
Bond AM, Ming GL, Song H (2015) Adult mammalian neural stem cells and neurogenesis: five decades later. Cell Stem Cell $17: 385-395$

Boutin C, Hardt O, de Chevigny A, Coré N, Goebbels S (2010) NeuroD1 induces terminal neuronal differentiation in olfactory neurogenesis. Proc Natl Acad Sci USA 107:1201-1206

Brill MS, Ninkovic J, Winpenny E, Hodge RD, Ozen I, Yang R, Lepier A, Gascón S, Erdelyi F, Szabo G, Parras C, Guillemot F, Frotscher M, Berninger B, Hevner RF, Raineteau O, Götz M (2009) Adult generation of glutamatergic olfactory bulb interneurons. Nature Neurosci 12:1524-1533

Bulfone A, Martinez S, Marigo V, Campanella M, Basile A, Quaderi N, Gattuso C, Rubenstein JL, Ballabio A (1999) Expression pattern of the Tbr2 (Eomesodermin) gene during mouse and chick brain development. Mech Dev 84:133-138

Cabrera-Socorro A, Hernandez-Acosta NC, Gonzalez-Gomez M, Meyer G (2007) Comparative aspects of p73 and Reelin expression in Cajal-Retzius cells and the cortical hem in lizard, mouse and human. Brain Res 1132:59-70

Campbell K, Götz M (2003) Radial glia: multi-purpose cells for vertebrate brain development. Trends Neurosci 25:235-238

Carrera I, Ferreiro-Galve S, Sueiro C, Anadón R, Rodríguez-Moldes I (2008) Tangentially migrating GABAergic cells of subpallial origin invade massively the pallium in developing sharks. Brain Res Bull 75:405-409

Ceci ML, Pedraza M, de Carlos JA (2012) The embryonic septum and ventral pallium, new sources of olfactory cortex cells. PLoS One 7:e44716

Charvet CJ, Stiedter GF (2009) Developmental origins of mosaic brain evolution: morphometric analysis of the developing zebra finch brain. J Comp Neurol 514:203-213

Charvet CJ, Owerkowicz T, Striedter GF (2009) Phylogeny of the telencephalic subventricular zone in sauropsids: evidence for the sequential evolution of pallial and subpallial subventricular zones. Brain Behav Evol 73:28-94

Cheung AFP, Pollen AA, Tavare A, Deproto J, Molnár Z (2007) Comparative aspects of cortical neurogenesis in vertebrates. J of Anat 211:164-176

Cheung AF, Kondo S, Abdel-Mannan O, Chodroff RA, Sirey TM, Bluy LE, Webber N, DeProto J, Karlen SJ, Krubitzer L, Stolp HB, Saunders NR, Molnár Z (2010) The subventricular zone is the developmental milestone of a 6-layered neocortex: comparisons in metatherian and eutherian mammals. Cereb Cortex 20:1071-1081

Clinton BK, Cunningham CL, Kriegstein AR, Noctor SC, MartínezCerdeño V (2014) Radial glia in the proliferative ventricular zone of the embryonic and adult turtle, Trachemys scripta elegans. Neurogenesis (Austin). https://doi.org/10.4161/23262 125.2014.970905

Coolen M, Menuet A, Chassoux D, Compagnucci C, Henry S, Lévèque L, Da Silva C, Gavory F, Samain S, Wincker P, Thermes C, D'Aubenton-Carafa Y, Rodriguez- Moldes I, Naylor G, Depew M, Sourdaine P, Mazan S (2009) The dogfish Scyliorhinus canicula, a reference in jawed vertebrates. In: Behringer RR, Johnson AD, Krumlauf RE (eds) Emerging model organisms, a laboratory manual, vol 1. Cold Spring Harbor Laboratory Press, Cold Spring Harbor, pp 431-446

Corbin JG, Nery S, Fishell G (2001) Telencephalic cells take a tangent: non-radial migration in the mammalian forebrain. Nat Neurosci 4 Suppl:1177-1182

Curto GG, Gard C, Rives V (2015) Structures and properties of PAX linked regulatory networks architecting and pacing the emergence of neuronal diversity. Semin Cell Dev Biol 44:75-86

D'Amico LA, Boujard D, Coumailleau P (2013) The neurogenic factor NeuroD1 is expressed in post-mitotic cells during juvenile and adult Xenopus neurogenesis and not in progenitor or radial glial cells. PLos One. https://doi.org/10.1371/journal.pone.0066487

D'Arcangelo G (2006) Reelin mouse mutants as models of cortical development disorders. Epilepsy Behav 8:81-90

Del Río JA, Soriano E, Ferrer I (1992) Development of GABA immunoreactivity in the neocortex of the mouse. J Comp Neurol 326:501-526

Dong Z, Yang N, Yeo SY, Chitnis A, Guo S (2012) Intralineage directional Notch signaling regulates self-renewal and differentiation of asymmetrically dividing radial glia. Neuron 74:65-78

Englund C, Flink A, Lau C, Pham D, Daza RA, Bulfone A, Kowalczyk T, Hevner RF (2005) Pax6, Tbr2, and Tbr1 are expressed sequentially by radial glia, intermediate progenitor cells, and postmitotic neurons in developing neocortex. J Neurosci 25(1):247-251

Espósito MS, Piatti VC, Laplagne DA, Morgenstern NA, Ferrari CC, Pitossi FJ, Schinder AF (2005) Neuronal differentiation in the adult hippocampus recapitulates embryonic development. J Neurosci 25:10074-10086

Farkas LM, Huttner WB (2008) The cell biology of neural stem and progenitor cells and its significance for their proliferation versus differentiation during mammalian brain development. Curr Opin Cell Biol 20:707-715

Favaro R, Valotta M, Ferri ALM, Latorre E, Mariani J, Giachino C, Lancini C, Tosetti V, Ottolenghi S, Taylor V, Nicolis SK (2009) Hippocampal development and neural stem cell maintenance require Sox2-dependent regulation of Shh. Nat Neurosci $12: 1248-1256$

Ferreiro-Galve S (2010) Brain and retina regionalization in sharks. Study based on the spatiotemporal expression pattern of Pax6 and other neurochemical markers. Ph.D. thesis, Universidade de Santiago de Compostela, Santiago de Compostela

Ferreiro-Galve S, Carrera I, Candal E, Villar-Cheda B, Anadón R, Mazan S, Rodríguez-Moldes I (2008) The segmental organization of the developing shark brain based on neurochemical markers, with special attention to the prosencephalon. Brain Res Bull 75:236-240

Ferreiro-Galve S, Rodríguez-Moldes I, Anadón R, Candal E (2010) Patterns of cell proliferation and rod photoreceptor differentiation in shark retinas. J Chem Neuroanat 39:1-14

Ferreiro-Galve S, Candal E, Rodríguez-Moldes I (2012a) Dynamic expression of Pax6 in the shark olfactory system: evidence for the presence of Pax6 cells along the olfactory nerve pathway. J Exp Zool B Mol Dev Evol 318:79-90

Ferreiro-Galve S, Candal E, Rodríguez-Moldes I (2012b) Pax6 expression during retinogenesis in sharks: comparison with markers of cell proliferation and neuronal differentiation. J Exp Zool B Mol Dev Evol 318:91-108

Ferri ALM, Cavallaro M, Braida D, Di Cristofano A, Canta A, Vezzani A, Ottolenghi S, Pandolfi PP, Sala M, DeBiasi S, Nicolis SK (2004) Sox 2 deficiency causes neurodegeneration and impaired neurogenesis in the adult mouse brain. Development 131:3805-3819

Gleeson JG, Allen KM, Fox JW, Lamperti ED, Berkovic S, Scheffer I, Cooper EC, Dobyns WB, Minnerath SR, Ross ME, Walsh CA (1998) Doublecortin, a brain-specific gen mutated in human X-linked Lissencephaly and double cortex syndrome, encodes a putative signaling protein. Cell 92:63-72

Gleeson JG, Lin PT, Flanaga LA, Walsh CA (1999) Doublecortin is a microtubule-associated protein and is expressed widely by migrating neurons. Neuron 23:257-271

Goffinet AM (1983) The embryonic development of the cortical plate in reptiles: a comparative study in Emys orbicularis and Lacerta agilis. J Comp Neurol 215:437-452

Goffinet AM, Bar I, Bernier B, Trujillo C, Raynaud A, Meyer G (1999) Reelin expression during embryonic brain development in lacertilian lizards. J Comp Neurol 414:533-550 
Götz M, Huttner WB (2005) The cell biology of neurogenesis. Nat Rev Mol Cell Biol 6:777-788

Götz M, Stoykova A, Gruss P (1998) Pax6 controls radial glia differentiation in the cerebral cortex. Neuron 21:1031-1044

Götz M, Sirko S, Beckers J, Irmler M (2015) Reactive astrocytes as neural stem or progenitor cells-in vivo lineage, in vitro potential, and genome-wide expression analysis. Glía 63:1452-1468

Guillemot F, Molnár Z, Tarabykin V, Stoykova A (2006) Molecular mechanisms of cortical differentiation. Eur J Neurosci 23:857-868

Hagey DW, Muhr J (2014) Sox 2 acts in a dose-dependent fashion to regulate proliferation of cortical progenitors. Cell Rep 9:1908-1920

Hamburger V, Hamilton HL (1951) A series of normal stages in the development of the chick embryo. J Morphol 88:49-92

Hatten ME (2002) New directions in neuronal migration. Science 297:1660-1663

Haubensak W, Attardo A, Denk W, Huttner WB (2004) Neurons arise in the basal neuroepithelium of the early mammalian telencephalon: a major site of neurogenesis. Proc Natl Acad Sci USA 101:3196-3201

Heins N, Malatesta P, Cecconi F, Nakafuku M, Tucker KL, Hack MA, Chapuoton P, Barde YA, Götz M (2002) Glial cells generate neurons: the role of the transcription factor Pax6. Nat Neurosci 5:308-315

Hevner RF, Neogi T, Englund C, Daza RA, Fink A (2003) Cajal-Retzius cells in the mouse: transcription factors, neurotransmitters, and birthdays suggest a pallial origin. Brain Res Dev Brain Res 141:39-53

Hevner RF, Hodge RD, Daza RA, Englund C (2006) Transcription factors in glutamatergic neurogenesis: conserved programs in neocortex, cerebellum, and adult hippocampus. Neurosci Res 55:223-233

Hodge RD, Kahoud RJ, Hevner RF (2012) Transcriptional control of glutamatergic differentiation during adult neurogenesis. Cell Mol Life Sci 69:2125-2134

Imamura F, Greer CA (2013) Pax6 regulates Tbr1 and Tbr2 expressions in olfactory bulb mitral cells. Trends Neurosci 37:77-84

Kosodo Y, Huttner WB (2009) Basal process and cell divisions of neural progenitors in the developing brain. Dev Growth Differ $51: 251-261$

Kriegstein A, Noctor S, Martínez-Cerdeño V (2006) Patterns of neural stem and progenitor cell division may underlie evolutionary cortical expansion. Nat Rev Neurosci 7:883-890

Lyons DA, Guy AT, Clarke JD (2003) Monitoring neural progenitor fate through multiple rounds of division in an intact vertebrate brain. Development 130:3427-3436

Malatesta P, Götz M (2013) Radial glia - from boring cables to stem cell stars. Development 140:483-486

Malatesta P, Appolloni I, Calzolari F (2008) Radial glia and neural stem cells. Cell Tissues Res 331:165-175

Marín O, Müller U (2014) Lineage origins of GABAergic versus glutamatergic neurons in the neocortex. Curr Opin Neurobiol 26:132-141

Martínez-Cerdeño V, Noctor SC, Kriegstein AR (2006) The role of intermediate progenitor cells in the evolutionary expansion of the cerebral cortex. Cereb Cortex 16(Suppl 1):152-61

Martínez-Cerdeño V, Cunningham CL, Camacho J, Keiter JA, Ariza J, Lovern M, Noctor SC (2016) Evolutionary origin of Tbr2expressing precursor cells and the subventricular zone in the developing cortex. J Comp Neurol. https://doi.org/10.1002/ cne. 23879

Martynoga B, Drechel D, Guillemot F (2015) Molecular control of neurogenesis: a view from the mammalian cerebral cortex. Cold Spring Harvor Lab Press
Medina L, Abellán A (2009) Development and evolution of the pallium. Semin Cell Dev Biol 20:698-711

Merrick SE, Pleasure SJ, Lurie DI, Pijak DS, Selzer ME, Lee VM (1995) Glial cells of the lamprey nervous system contain keratinlike proteins. J Comp Neurol 355:199-210

Mione M, Shanmugalingam S, Kimelman D, Griffin K (2001) Overlapping expression of zebrafish T-brain-1 and eomesodermin during forebrain development. Mech Dev 100:93-97

Miyata T, Kawaguchi A, Saito K, Kawano M, Muto T, Ogawa M (2004) Asymmetric production of surface-dividing and non-surfacedividing cortical progenitor cells. Development 131:3133-3145

Montiel JF, Vasistha NA, Garcia-Moreno F, Molnár Z (2015) From sauropsids to mammals and back: new approaches to comparative cortical development. J Comp Neurol 524:630-645

Moreno N, González A (2017) Pattern of neurogenesis and identification of neuronal progenitor subtypes during pallial development in Xenopus laevis. Front Neuroanat 11:24

Mueller T, Wulliman MF (2003) Anatomy of neurogenesis in the early zebrafish brain. Brain Res Dev Brain Res 140:137-155

Mueller T, Wulliman MF (2016) Atlas of early zebrafish brain development. Elsevier. ISBN:978012417269

Mueller T, Wullimann MF, Guo S (2008) Early teleostean basal ganglia development visualized by zebrafish $D l x 2 a$, Lhx6. Lhx7, Tbr2 (eomeasa) and GAD67 gene expression. J Comp Neurol 507:1245-1257

Mueller T, Dong Z, Berberoglu MA, Guo S (2011) The dorsal pallium in zebrafish, Danio rerio (Cyprinidae, Teleostei). Brain Res 1381:95-105

Nieuwenhuys R (1994) The neocortex. An overview of its evolutionary development, structural organization and synaptology. Anat Embryol (Berl) 190:307-337

Nieuwenhuys R, Nicholson C (1998) Lampreys, petromyzontoidea. In: Nieuwenhuys R, Donkelaar T, Nicholson C (eds) The central nervous system of vertebrates, vol 1. Springer, Berlin, pp 397-495

Noctor SC, Martinez-Cerdeño V, Ivic L, Kriegstein AR (2004) Cortical neurons arise in symmetric and asymmetric division zones and migrate through specific phases. Nat Neurosci 7:136-144

Nomura T, Ohtaka-Maruyama C, Yamashita W, Wakamatsu Y, Murakami Y, Calegari F, Suzuki K, Gotoh H, Ono K (2016) The evolution of basal progenitors in the developing non-mammalian brain. Development (Cambridge England) 143:66-74

Pedraza M, De Carlos JA (2012) A further analysis of olfactory cortex development. Front Neuroanat 6:35

Pombal MA, Alvarez-Otero R, Pérez-Fernández J, Solveira C, Megías M (2011) Development and organization of the lamprey telencephalon with special reference to the GABAergic system. Front Neuroanat 5:20

Pose-Méndez S, Candal E, Adrio F, Rodríguez-Moldes I (2014) Development of the cerebellar afferent system in the shark Scyliorhinus canicula: insights into the basal organization of precerebellar nuclei in gnathostomes. J Comp Neurol 522:131-168

Pose-Méndez S, Candal E, Mazan S, Rodríguez-Moldes I (2016a) Genoarchitechture of the rostral hindbrain of a shark: basis for understanding the emergence of the cerebellum at the agnathangnathostome transition. Brain Struct Funct 221:132135

Pose-Méndez S, Candal E, Mazan S, Rodríguez-Moldes I (2016b) Morphogenesis of the cerebellum and cerebellum-related structures in the shark Scyliorhinus canicula: insights on the ground pattern of the cerebellar ontogeny. Brain Struct Funct 221:1691-1717

Pose-Méndez S, Rodríguez-Moldes I, Candal E, Mazan S, Anadón R (2017) A developmental study of the cerebellar nucleus in the catshark, a basal gnathostome. Brain Behav Evol. https://doi. org/10.1159/000453654 
Quintana-Urzainqui I, Rodríguez-Moldes I, Candal E (2014) Developmental, tract-tracing and immunohistochemical study of the peripheral olfactory system in a basal vertebrate: insights on Pax6 neurons migrating along the olfactory nerve. Brain Struct Funct 219:85-104

Quintana-Urzainqui I, Rodríguez-Moldes I, Mazan S, Candal E (2015) Tangential migratory pathways of subpallial origin in the embryonic telencephalon of sharks: evolutionary implications. Brain Struct Funct 220:2905-2926

Rakic P (2009) Evolution of the neocortex: a perspective from developmental biology. Nat Rev Neurosci 10:724-735

Rash BG, Tomasi S, Lim HD, Suh CY, Vaccarino FM (2013) Cortical gyrification induced by fibroblast growth factor 2 in the mouse brain. J Neurosci 45(3):306-312

Reillo I, de Juan Romero C, García-Cabezas M, Borrell V (2011) A role for intermediate radial glia in the tangential expansion of the mammalian cerebral cortex. Cereb Cortex 21:1674-1694

Rodríguez-Moldes I (2009) A developmental approach to forebrain organization in elasmobranchs: new perspectives on the regionalization of the telencephalon. Brain Behav Evol 74:20-29

Rodríguez-Moldes I, Ferreiro-Galve S, Carrera I, Sueiro C, Candal E, Mazan S, Anadón R (2008) Development of the cerebellar body in sharks: spatiotemporal relations of Pax6 expression, cell proliferation and differentiation. Neurosci Lett 432:105-110

Rodríguez-Moldes I, Carrera I, Pose-Méndez S, Quintana-Urzainqui I, Candal E, Anadón R, Mazan S, Ferreiro-Galve S (2011) Regionalization of the shark hindbrain: a survey of an ancestral organization. Front Neuroanat 5:16

Rodríguez-Moldes I, Santos-Durán GN, Pose-Méndez S, QuintanaUrzainqui I, Candal E (2017) The brains of cartilaginous fishes. In: Kaas J (ed) Evolution of nervous systems 2e, vol 1. Elsevier, Oxford, pp 77-97, ISBN:9780128040423

Roybon L, Deierborg T, Brundin P, Li JY (2009) Involvement of Ngn2, Tbr and NeuroD proteins during postnatal olfactory bulb neurogenesis. Eur J Neurosci 29:232-243

Sánchez-Farías N, Candal E (2015) Doublecortin is widely expressed in the developing and adult retina of sharks. Exp Eye Res 134:90-100

Sánchez-Farías N, Candal E (2016) Identification of radial glia progenitors in the developing and adult retina of sharks. Front Neuroanat 10:65

Santos-Durán GN, Menuet A, Lagadec R, Mayeur H, Ferreiro-Galve S, Mazan S, Rodríguez-Moldes I, Candal E (2015) Prosomeric organization of the hypothalamus in an elasmobranch, the catshark Scyliorhinus canicula. Front Neuroanat 9:37

Santos-Durán GN, Ferreiro-Galve S, Menuet A, Quintana-Urzainqui I, Mazan S, Rodríguez-Moldes I, Candal E (2016) The shark alar hypothalamus: molecular characterization of prosomeric subdivisions and evolutionary Trends. Front Neuroanat 10:113

Sauer FC (1935) Mitosis in the neural tube. J Comp Neurol 62:377-405

Shimozaki K (2014) Sox2 transcription network acts as a molecular switch to regulate properties of neural stem cells. World J Stem Cells 6:485-490

Smart IH, Dehay C, Giroud P, Berland M, Kennedy H (2002) Unique morphological features of the proliferative zones and postmitotic compartments of the neural epithelium giving rise to striate and extrastriate cortex in the monkey. Cereb Cortex 12:37-53
Stiedter GF (2015) Neurobiology: a functional approach. Oxford University Press, Oxford

Striedter GF, Charvet CJ (2008) Developmental origins of species differences in telencephalon and tectum size: morphometric comparisons between a parakeet (Melopsittacus undulatus) and a quail (Colinus virgianus). J Comp Neurol 507:1663-1675

Striedter GF, Charvet CJ (2009) Telencephalon enlargement by the convergent evolution of expanded subventricular zones. Biol Lett 5:134-137

Striedter GF, Keefer BP (2000) Cell migration and aggregation in the developing telencephalon: pulse-labeling chick embryos with bromodeoxyuridine. J Neurosci 20:8021-8030

Tissir F, Lambert De Rouvroit C, Sire JY, Meyer G, Goffinet AM (2003) Reelin expression during embryonic brain development in Crocodylus niloticus. J Comp Neurol 457:250-262

Venkatesh B, Lee AP, Ravi V, Maurya AK, Michelle M, Swann JB, Ohta Y, Flajnik MF, Sutoh Y, Hoon S, Gangu V, Roy SW, Irimia M (2014) https://doi.org/10.1038/nature12826.Elephant

Wasowicz M, Ward R, Repérant J (1999) An investigation of astroglial morphology in torpedo and scyliorhinus. J Neurocytol 28:639-653

Wicht H, Derouiche A, Korf HW (1994) An immunocytochemical investigation of glial morphology in the Pacific hagfish: radial and astrocyte-like glia have the same phylogenetic age. J Neurocytol 23:565-576

Wulliman MF (2009) Secondary neurogenesis and telencephalic organization in zebrafish and mice: a brief review. Integr Zool 4:123-133

Wulliman MF, Puelles L (1999) Postembryonic neural proliferation in the zebrafish forebrain and its relationship to prosomeric domains. Anat Embryo 329:329-348

Wullimann MF, Knipp S (2000) Proliferation pattern changes in the zebrafish brain from embryonic through early postembryonic stages. Anat Embryol 202:385-400

Wullimann MF, Rink E (2001) Detailed immunohistology of Pax6 protein and tyrosine hydroxylase in the early zebrafish brain suggests role of Pax6 gene in development of dopaminergic diencephalic neurons. Dev Brain Res 131:173-191

Wullimann MF, Rink E (2002) The teleostean forebrain: A comparative and developmental view based on early proliferation, Pax6 activity and catecholaminergic organization. Brain Res Bull $57: 363-370$

Yopak KE, Lisney TJ, Collin SP (2015) Not all sharks are "swimming noses": variation in olfactory bulb size in cartilaginous fishes. Brain Struct Funct 220:1127-1143

Zecevic N, Chen Y, Filipovic R (2005) Contributions of cortical subventricular zone to the development of the human cerebral cortex. J Comp Neurol 491:109-122

Zerjatke T, Gak IA, Kirova D, Fuhrmann M, Daniel K, Gonciarz M, Müller D, Glauche I, Mansfeld J (2017) Quantitative cell cycle analysis based on an endogenous all-in-one reporter for cell tracking and classification. Cell Rep 19:1953-1966

Zhang S, Cui W (2014) Sox2, a key factor in the regulation of pluripotency and neural differentiation. World J Stem Cells 6:305-311 